Original Research

\title{
The Carbon Dioxide Emissions Reduction Potential of Carbon-Dioxide- Cured Alternative Binder Concrete
}

\author{
Sampo Mäkikouri *, Sirje Vares, Kirsi Korpijärvi, Nikolaos Papakonstantinou
}

VTT Technical Research Centre of Finland Ltd., Visiokatu 4, 33720 Tampere, Finland; E-Mails: sampo.makikouri@vtt.fi; Sirje.Vares@vtt.fi; Kirsi.Korpijarvi@vtt.fi; Nikolaos.Papakonstantinou@vtt.fi

* Correspondence: Sampo Mäkikouri; E-Mail: sampo.makikouri@vtt.fi

Academic Editor: Aritra Ghosh

Special Issue: Wastes, Residues and Byproducts for the Production of Construction Materials

Recent Progress in Materials

2021, volume 3, issue 2

doi:10.21926/rpm.2102017
Received: January 12, 2021

Accepted: April 07, 2021

Published: May 13, 2021

\begin{abstract}
Climate change has been identified as one of the biggest issues plaguing human life at present. Hence, immense attention is being paid to developing methods that can potentially reduce carbon dioxide emission. With the help of carbon-negative concrete, manufactured from alternative binders and cured with waste carbon dioxide, a major part of the manufacturing industries that emit carbon dioxide can be potentially turned into a carbon sink. In this study, the waste material streams in Finland, suitable for disposing carbon-dioxide-cured concrete, were mapped. Mine tailings, blast furnace and steel slags, recycled concrete, biomass, coal and municipal waste incineration ashes, green liquor dregs, and foundry sands were studied. It was found that there were sufficient amounts of potential secondary raw materials (about $27 \mathrm{Mt} / \mathrm{a}$ ) for the preparation of Finnish cement and the production of concrete (requirement: approximately $1.4 \mathrm{Mt} / \mathrm{a}$ and $11.2 \mathrm{Mt} / \mathrm{a}$, respectively). The total carbon dioxide uptake potential was estimated to be approximately $1.9 \mathrm{Mt} / \mathrm{a}$ (vs. emissions from the cement industry in Finland, $0.84 \mathrm{Mt} / \mathrm{a}$ ). In addition, the carbon footprints of the conventionally manufactured concrete block were compared with the carbon footprint produced by a modeled carbon-dioxide-cured blast furnace slag block. If such novel concrete were used to
\end{abstract}

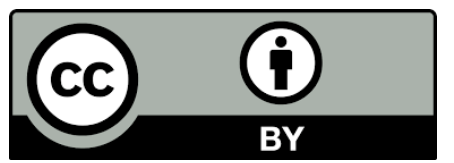

(c) 2021 by the author. This is an open access article distributed under the conditions of the Creative Commons by Attribution License, which permits unrestricted use, distribution, and reproduction in any medium or format, provided the original work is correctly cited. 
produce all the concrete-based substances, it would bring down the emission of carbon dioxide from $1.9 \%$ to negative $1.3 \%$ in Finland.

\section{Keywords}

Concrete; alternative binder; mineralization; circular economy; carbon footprint

\section{Introduction}

Climate change is one of the largest problems faced by humanity in our time. The importance of reducing the emission of greenhouse gas by 2030 , especially in the industry and transportation sectors, is stressed in the IPCC $1.5{ }^{\circ} \mathrm{C}$ report [1]. The Finnish government has reacted to this global concern by setting an ambitious goal. The government programme aims to reach carbon neutrality in Finland by 2035 [2]. In this paper, $\mathrm{CO}_{2}$-cured, carbon-negative concrete is studied as a means of reducing $\mathrm{CO}_{2}$ emissions in the cement and concrete industry in Finland (an example case). The goal of the study is to find out whether $\mathrm{CO}_{2}$-cured concrete could potentially be used to reduce emissions in Finland. The research questions are as follows:

- What kind of material streams could be suitable for achieving large-scale $\mathrm{CO}_{2}$-cured concrete in Finland?

- How big are the volumes in which those material streams are available in Finland?

- What is the $\mathrm{CO}_{2}$ uptake potential in the selected material streams?

- How does the carbon footprint of a modeled $\mathrm{CO}_{2}$-cured blast furnace slag block compare with that of a conventional concrete block?

We expect to obtain vital information on the $\mathrm{CO}_{2}$ emission reduction potential, sustainability, and limitations of the carbon-negative concrete concept. Moreover, we aim to gain necessary insights on the role of major parameters of the carbon-negative concrete concept, such as the raw material selection process and transportation distance for the carbon footprint of the product.

\section{Background}

\section{$2.1 \mathrm{CO}_{2}$ Emission during Cement and Concrete Production}

Global cement production of over $4000 \mathrm{Mt}$ per year accounts for $8 \%$ of the global $\mathrm{CO}_{2}$ emission [3]. This is more than three times the $\mathrm{CO}_{2}$ emission from global aviation [4]. Most of the emissions originate from two sources in the cement kiln: about $40 \%$ of the emission can be attributed to the combustion of fuels (about 30\% in Finland due to energy efficiency and waste fuels) and about $50 \%$ from the calcination reaction (about 60\% in Finland) as presented in Equation 1 as follows:

$$
\mathrm{CaCO}_{3} \rightarrow \mathrm{CaO}+\mathrm{CO}_{2}
$$

where calcium carbonate decomposes into carbon dioxide and calcium oxide, an important constituent of conventional cement. Approximately $10 \%$, is related to raw material grinding and transportation $[5,6]$. The global average for total $\mathrm{CO}_{2}$ emission per ton of cement is approximately $890 \mathrm{~kg} \mathrm{CO} /$ t cement [7]. 
In Finland, the total production volume of cement in 2016 was 1.34 Mt (or 1.12 Mt as clinker), the emissions at the cement plants were $0.827 \mathrm{Mt}$ of $\mathrm{CO}_{2}$ (excluding raw material processing and transportation), and the average $\mathrm{CO}_{2}$ emissions per ton of cement (CEM I) was approximately 740 $\mathrm{kg} \mathrm{CO}_{2} / \mathrm{t}$ cement [6]. Quarries of raw-materials are present around Finnsementti (e.g., limestone is produced in Nordkalk). These constitute the secondary raw materials, resulting in low amounts of pre-factory emissions. Approximately $1.1 \mathrm{~kg} / \mathrm{kg}$ of cement and $0.3 \mathrm{~kg} / \mathrm{kg}$ of other raw materials, such as fly ash and blast furnace slag, are required for cement production [8]. Approximately $2-5 \mathrm{~g}$ of $\mathrm{CO}_{2} / \mathrm{kg}$ is produced from natural stone according to the different Environmental product declarations (EPDs) presented in the Finnish construction database for $\mathrm{CO}_{2}$ production [9]. Other raw materials, wastes (fly ash), or byproducts (slags) exert little or no [10] impact on the process. The process of transportation of raw materials does not exert a significant impact because most of the main raw material (e.g., limestone) is available nearby, and the specific emission is 39 $\mathrm{gCO}_{2} \mathrm{e} /$ tonne-km [11]. Thus, it is estimated that the total share of $\mathrm{CO}_{2}$ emission for the raw material acquisition process is approximately $1.5 \%(1-2 \%)$ of the emission during the production of Finnish cement. The total emission during the production of cement can be expressed by Equation 2 as follows:

$$
\begin{aligned}
& \text { Total emissions of cement }=\text { Emissions of cement plants } \\
& \qquad \begin{array}{c}
/(100 \%-\text { emissions of raw materials }[\%]) \\
=0.839 \mathrm{Mt} \mathrm{CO}_{2}
\end{array}
\end{aligned}
$$

This corresponds to $1.4 \%$ of the total greenhouse gas emission (58.8 $\mathrm{Mt} \mathrm{CO}_{2}$ ) in Finland in 2016 [12]. In addition to the emissions from cement, the concrete industry greenhouse gases can also be emitted from aggregate and additive use. Emissions can also be attributed to the transportation process and concrete production energy. The most greenhouse gases is emitted from cement used for the preparation of concrete; however, the share varies from product to product. The annual steel consumption of the concrete industry in 2016 was 56700 t/a [13], and the related $\mathrm{CO}_{2}$ emissions were approximately $0.113 \mathrm{Mt} / \mathrm{a}$ when the assumed specific $\mathrm{CO}_{2}$ emissions of steel were $2.0 \mathrm{t} \mathrm{CO}_{2} / \mathrm{t}$ steel [14] (p.7). The total amount of greenhouse gases emitted during the production of cement and concrete in Finland can be estimated using Equation 3.

Total $\mathrm{CO}_{2}$ emissions of concrete and cement industry including reinforcements

$$
=\mathrm{CO}_{2} \text { emissions of cement }\left[\frac{\mathrm{Mt}}{a}\right]
$$

/Fraction of cement related emissions from concrete emissions [\%]

$$
\begin{aligned}
& + \text { CO2 emissions of steel used for concrete }\left[\frac{M t}{a}\right] \\
& =0.839 \mathrm{Mt} \mathrm{CO} \mathrm{C}_{2} / \mathrm{a} / 0.85+0.113 \mathrm{MtCO}_{2} / \mathrm{a}=1.1001 \mathrm{Mt} \mathrm{CO} 2 / \mathrm{a} \approx 1.1 \mathrm{MtCO}_{2} / \mathrm{a}
\end{aligned}
$$

This was approximately $1.9 \%$ of the entire $\mathrm{CO}_{2}$ emission in Finland. The actual annual emission from the cement and concrete industry depends on the cement export and import volumes. $\mathrm{CO}_{2}$ emissions from the imported cement (the year 2016 was chosen because there was no export or import of cement), fluctuations in the construction markets, and changes in manufactured product types were studied. 


\subsection{Carbonation of Concrete}

The carbonation of concrete is the process where concrete reacts with carbon dioxide, either via the natural carbonation process (occurring over years when concrete stays in contact with atmospheric $\mathrm{CO}_{2}$ during use, at the end-of-life phase, and beyond the life cycle) or the accelerated carbonation process ( $\mathrm{CO}_{2}$ curing of concrete products).

Carbonation is often considered undesirable because it lowers the $\mathrm{pH}$ of concrete, resulting in the corrosion of steel reinforcements. The safe $\mathrm{pH}$ level for the protection of steel reinforcements is estimated to be higher than 9.5 [15]. However, carbonation also has positive impacts as it increases the compressive and tensile strength of concrete. Recently, it has been revealed that it can act as a potential sink for atmospheric carbon [16-18]. The current research on the natural carbonation of concrete has focused on modeling and optimizing the later stages of the life cycle by increasing the exposed surface area. The surface area was increased by crushing it. The resulting aggregate should be exposed to ambient air conditions for many years (or decades) to achieve high $\mathrm{CO}_{2}$ uptake [19-21].

The chemical reaction for carbonation is expressed as follows [22]:

$$
\mathrm{Ca}(\mathrm{OH})_{2}+\mathrm{CO}_{2} \rightarrow \mathrm{CaCO}_{3}+\mathrm{H}_{2} \mathrm{O}
$$

The theoretical maximum $\mathrm{CO}_{2}$ uptake correlates to the amount of $\mathrm{CaO}$ in binders. According to the simplified approach, maximum theoretical $\mathrm{CO}_{2}$ uptake can be calculated as follows [22]:

$$
U_{t c c}=w^{*} C_{c}{ }^{*}\left(\frac{m C O_{2}}{m C a O}\right)
$$

where $\mathrm{U}_{\text {tcc }}$ is the maximum theoretical uptake of $\mathrm{CO}_{2}$ in totally carbonated concrete [kg]; w represents reactive $\mathrm{CaO}\left[\mathrm{kg} \mathrm{CaO} / \mathrm{kg}\right.$ binder]; $\mathrm{C}_{\mathrm{C}}$ is the mass of clinker $[\mathrm{kg}] ; \mathrm{mCO}_{2}$ denotes the molar weight of $\mathrm{CO}_{2}(44 \mathrm{~g} / \mathrm{mol})$; and $\mathrm{mCaO}$ denotes the molar weight of $\mathrm{CaO}(56 \mathrm{~g} / \mathrm{mol})$.

The $\mathrm{CO}_{2}$ uptake (carbonation) capacity for the cement types CEM I/A, CEM II/A, and CEM II/B were found to be $0.49,0.41$, and $0.36 \mathrm{~kg} \mathrm{CO}_{2} / \mathrm{kg}$ cement, respectively. These values also differ largely in conventional types of cement. The prerequisite was that reactive $\mathrm{CaO}$ should constitute $65 \%$ and the clinker fraction should constitute $95 \%, 80 \%$, or $70 \%$ of the total amount [22].

During the process of carbonation, $\mathrm{CO}_{2}$ from the atmosphere diffuses into the concrete through the surface. The carbonation depth is approximately proportional to the square root of time. The total quantity of $\mathrm{CO}_{2}$ taken up during the use phase depends on the concrete application, time of concrete exposure, concrete porosity, type of cement used, and water/cement ratio.

The carbonation depth coefficient $(k)$ under conditions of varying concrete strength (cylinder), exposure times, and degree of carbonation $\left(D_{c}\right)$ can be calculated according to the protocol presented in EN 16757 [22]. $\mathrm{CO}_{2}$ uptake $\left(\mathrm{kg} / \mathrm{m}^{2}\right.$ of the concrete surface) over the number of years $t$ can be calculated as follows:

$$
C O_{2} \text { uptake }=k^{*} K_{c}^{*}\left(\frac{\sqrt{t}}{1000}\right)^{*} U_{t c c}{ }^{*} C^{*} D_{c},
$$

where $k$ is a coefficient, which takes into account concrete strength and conditions [16], outlined in EN 16757 (Table BB.1) [22], $\mathrm{K}_{\mathrm{c}}$ is the correction factor that takes into account cement containing additional constituents or concrete with mineral additives, $U_{\text {tcc }}$ is the maximum theoretical uptake 
in $\mathrm{kg} \mathrm{CO} / \mathrm{kg}$ cement ( 0.49 for Portland cement (CEM I), presented above), $\mathrm{C}$ is the cement content in $\mathrm{kg} / \mathrm{m}^{3}$ of concrete, $D_{c}$ is a coefficient that takes into account the degree of carbonation [16], present in EN 16757 (Table BB.1) [22].

Using the above equation for a concrete sample with a service life of 100 years, the $\mathrm{CO}_{2}$ uptake could be $2.5 \mathrm{~kg} / \mathrm{m}^{2}$ (indoor conditions; cement content: $280 \mathrm{~kg} / \mathrm{m}^{3}$ ) and $1.8 \mathrm{~kg} / \mathrm{m}^{2}$ (exposed surface and cement content $400 \mathrm{~kg} / \mathrm{m}^{3}$ ). The calculation of carbonation depth depends on the exposure conditions. Hence, a lower-strength concrete can potentially exhibit a higher carbonation depth as the correction factor under indoor conditions is significantly higher than the correction factor of the higher-strength concrete under outdoor conditions, which was also exposed to rain (correction factors for those were accordingly 1.1 and 4.6). The precise theoretical $\mathrm{CO}_{2}$ uptake can be calculated for all types of concrete used in buildings using Equation 6.

At the end of life, when all the prerequisites are as described, improved carbonation can be achieved using concrete ground into small particles. When laboratory-based experiments were conducted under conditions of optimal humidity and pressure that is 10-100 times the atmospheric $\mathrm{CO}_{2}$ partial pressure, up to $50-90 \%$ of the total $\mathrm{CaO}$ was carbonated in medium to high watercement ratio concretes. [21] The results from a case study where the Itaipu Dam was studied revealed that when 12.7 million cubic meters of concrete was used, the structure had absorbed 13,384 tons of $\mathrm{CO}_{2}$ during service life of 35 years [23], which was about $0.5 \%$ or less of the $\mathrm{CO}_{2}$ emission from the used concrete. However, the results obtained from the carefully conducted onsite experiments for the process of natural carbonation (especially that obtained at the end of the life cycle) is still incomprehensive.

\subsection{Carbonation of Secondary Raw Material}

Alkaline waste material streams usually contain calcium, magnesium, potassium, and sodium oxides that make them suitable for carbon capture and storage. It has been verified that these waste materials are capable of binding $\mathrm{CO}_{2}$, and the process can be accelerated following various treatment methods [24-28]. Reactive waste materials need less pre-treatment and less energyintensive carbonation conditions in comparison to raw minerals [29]. High variability in waste volumes and chemical composition is a major obstacle in the field of carbon capture and storage [27].

It has been estimated that the current global annual $\mathrm{CO}_{2}$ uptake potential of alkaline material streams via carbonation is $1 \mathrm{GtCO}_{2}$, and it may increase to $2.3-3.3 \mathrm{GtCO}_{2}$ by 2050 and 2.9-5.9 $\mathrm{GtCO}_{2}$ by 2100 [30]. Blast furnace and steel slag, red mud, cement kiln dust, concrete in building products and demolition waste, ultramafic waste rock and mine tailings, and fuel ashes were studied.

\subsection{Alternative Methods to Achieve Reduced $\mathrm{CO}_{2}$ Emission in the Concrete Sector}

The proposed measures for further lowering the emissions from concrete include the use of alternative fuels. Levels of emission can also be lowered by decreasing the amount of clinker in cement (for example, the use of supplementary cementitious materials (SCM)), using novel cement), or adopting carbon capture and storage (CCS). The processes can result in reduced cement demand with a better design and longer lifetime $[3,7,31,32]$. Even though all these measures are significant for a quick and cost-efficient reduction of emissions, only novel cements and CCS have the potential to make concrete carbon-neutral [3] (Figure 1). Thus, widespread use of novel clinker-free cement, 
the implementation of CCS to all cement kilns, or a combination of both will be essential to develop a concrete industry that is striving to become carbon neutral.

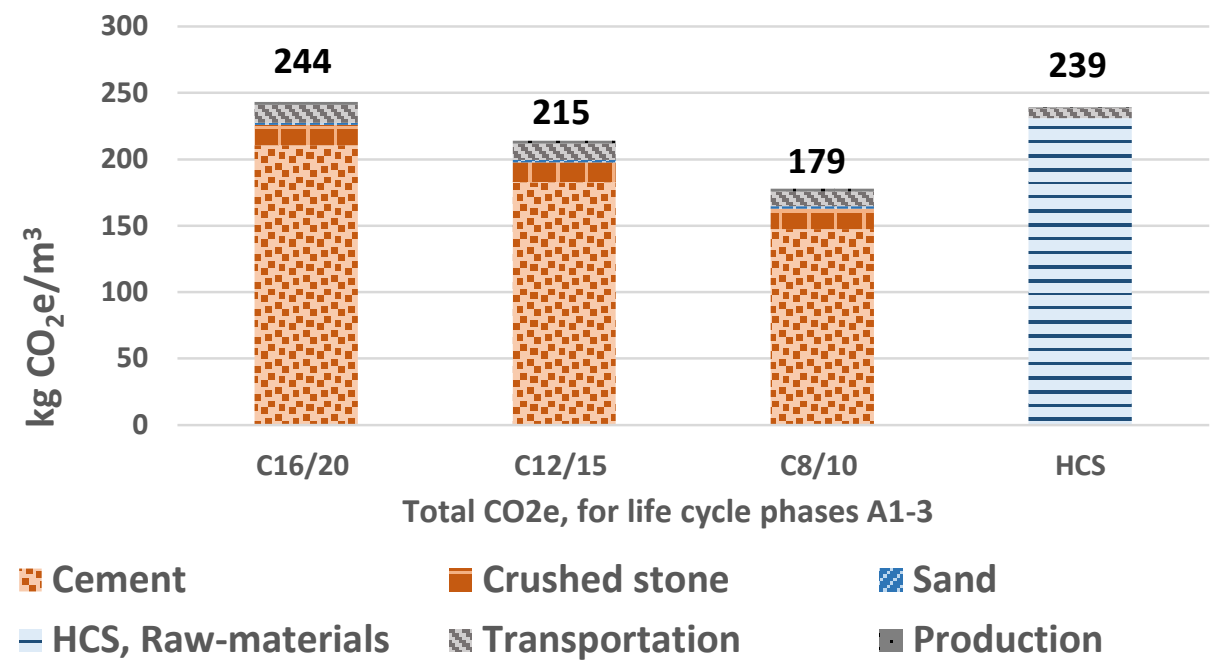

Figure 1 Carbon footprint of conventional concretes of different strengths and a hollow core slab (HCS) (life cycle stages A1-3).

\subsubsection{Novel Cement and SCMs}

The replacement of Ordinary Portland Cement (OPC) with novel binders, entirely or in part, with supplementary cementitious materials, is a complex process. Firstly, the current standard for cement limits the raw materials used in cement mixtures: $95 \mathrm{wt} . \%$ or more must be clinker, blast furnace slag, silica fume, pozzolana, coal fly ash, burnt shale, or limestone [33]. In Figure 2, the share of blending components in common Finnish cement is presented [34].

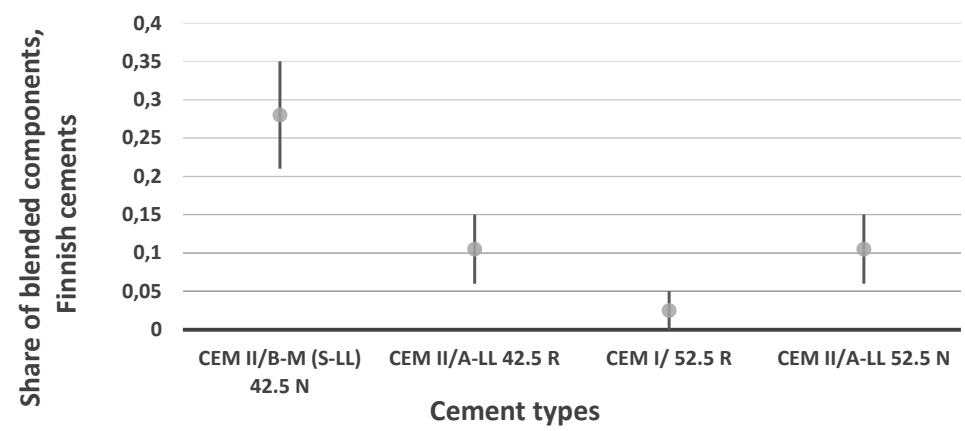

Figure 2 Mass fractions of blending components used in Finnish cement. For cement, blending limestone and blast furnace slag are used.

Secondly, the properties of cement, such as strength development, are affected by the composition of the clinker, the mineral binder additives used, and the fineness of the cement. For example, the difference between cement CEM I $42.5 \mathrm{R}$ and CEM II/A $42.5 \mathrm{R}$ lies primarily in their binder additive content. CEM I does not contain more than $5 \%$ of the additives, whereas CEM II/A 
may contain $6-20 \%$ of additives. Both types of cement belong to the same strength class, and at the age of 28 days, the strength must be at least $42.5 \mathrm{MPa}$.

The alternatives can be used to lower the carbon footprint of concrete. However, when substituting OPC with high amounts of fly ash or blast furnace slag, the compressive strength decreases with the increase in the amount of Portland cement replaced [35]. Moreover, all changes in the materials must be designed and tested carefully to provide safe materials for long-lasting use. Thus, piloting in low-risk environments is necessary.

\subsubsection{Carbon Capture and Storage}

Building carbon capture, transportation and storage systems take time, because there are no suitable geological formations for CCS in Finland [36]. $\mathrm{CO}_{2}$ should be transported, for example, by ship to Norway to a $\mathrm{CO}_{2}$ hub [37,38]. Moreover, the urgency of building CCS capabilities contradicts short-term business sense as long as it is cheaper to pay for the $\mathrm{CO}_{2}$ emission allowance price that is currently approximately $44 € / t \mathrm{CO}_{2}$ [39] compared to the CCS cost for cement kilns that is approximately $40-80 € / \mathrm{t} \mathrm{CO}_{2}$ [40] (Figure 3). Nevertheless, CCS, alternative energy sources, and energy efficiency are seen as the most feasible large-scale emission reduction method that will be employed by the concrete industry in Finland by 2030 [41, 42]

\section{Raw-materials, hollow core slab [wt\%]}

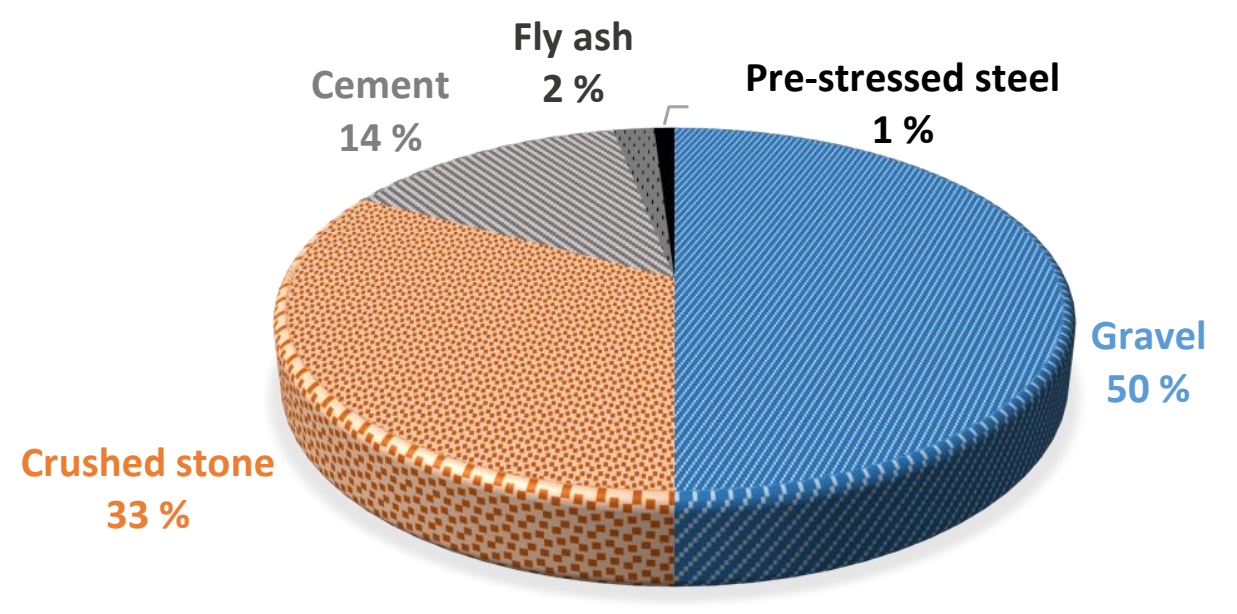

Figure 3 Raw material shares of a representative hollow core slab [43].

Long international transportation of $\mathrm{CO}_{2}$ could be avoided following the process of mineralization, an alternative to geological storage. During the process of mineralization, crushed rock, like serpentinite, or industrial waste streams, like steelmaking slags and ashes, react with $\mathrm{CO}_{2}$ of the flue gases. Minerals such as carbonates are formed [44, 45]. Although serpentinite is available in Finland in enough quantities for $\mathrm{CCS}$, mineralization in serpentinite for $\mathrm{CO}_{2}$ storage requires high energy costs for the regeneration of used chemicals $[45,46]$. The European legal framework for CCS and ETS currently only includes geological storage [47], and thus, mineralization does not yet bring the same cost savings from the reduced amount of emission allowance needed. However, a legal case 
on $\mathrm{CO}_{2}$ captured from a lime kiln and transported to precipitated $\mathrm{CaCO}_{3}$ production [48] shows that $\mathrm{CO}_{2}$ captured from a cement kiln and used for concrete production might be an even faster way of reducing emission allowance. In any case, compensation and emission removal markets can already bring additional revenue.

\subsubsection{Carbon-Negative Concrete Production}

Carbon-negative concrete manufactured using alternative binders and cured with waste $\mathrm{CO}_{2}$ has been proposed as one solution to mitigate the climate impact of concrete $[3,31,49]$. It can be viewed as a combination of novel cement and CCS: permanent carbon capture via mineralization with financial benefits from the manufactured product. The product performance is a limitation. If these demands can be addressed, the concept appears to promote all aspects of sustainability with lower environmental impact. The economic value can be increased by utilizing waste, and new job opportunities can be created. The diagram in Figure 4 illustrates the main features of the carbonnegative concrete concepts.

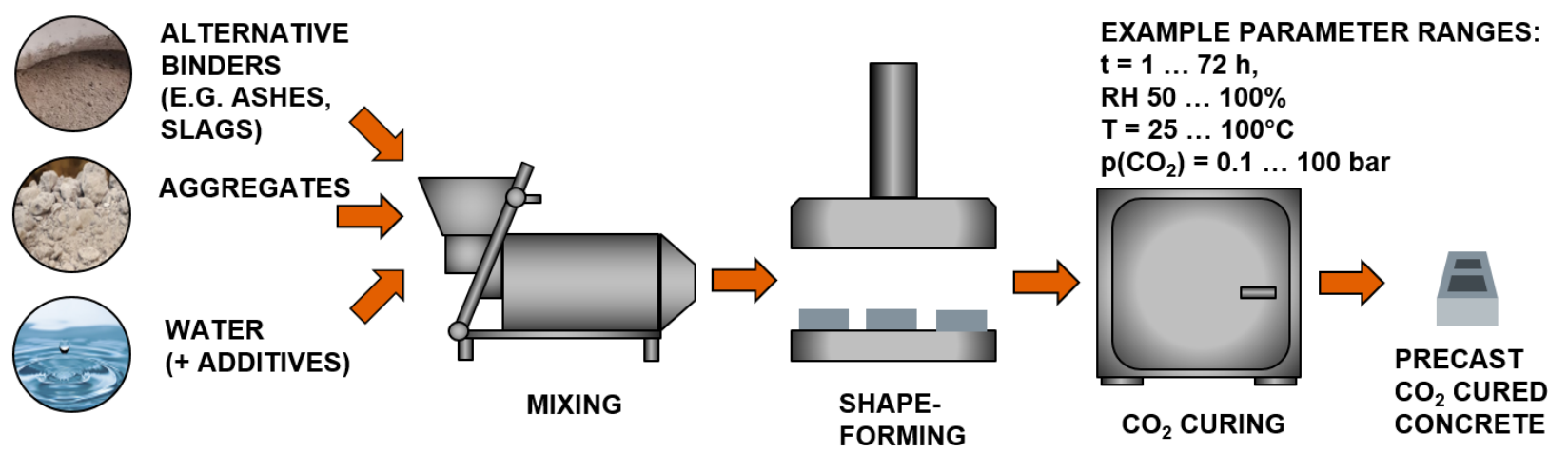

Figure 4 Schematic representation of a precast $\mathrm{CO}_{2}$-cured concrete product.

The main difference lies in the curing phase, where the fresh concrete is placed in a $\mathrm{CO}_{2}$-rich atmosphere. Carbon-containing minerals, mainly carbonates, are formed. The material is hardened following various reactions (other than the hydration reaction). The process is similar to that observed during the hardening of conventional concrete [44]. In addition, the raw mix may or may not contain Ordinary Portland cement. Both ready-mix and precast concrete can find their applications [50-52]. In recent years, several interesting precast concrete applications in the presence of alternative cementitious materials, like steelmaking slags or coal fly ash, have emerged that claim to generate carbon-negative footprints [52-54]. This is possible if the binder material has a very low carbon footprint, significant amounts of waste $\mathrm{CO}_{2}$ are bound, the processing is not very carbon-intensive, and the transportation distances are reasonable. However, it has been recently cautioned that not all $\mathrm{CO}_{2}$ utilization methods adopted by the concrete manufacturing industry necessarily result in climate benefits. A life-cycle assessment approach is required to determine the benefits [55]. Previous research has focused on the $\mathrm{CO}_{2}$ uptake in specific materials and the mechanical properties of concrete samples manufactured from those materials. The roles of temperature, pressure, humidity, and duration of the curing process have also been studied [28, 5658]. Also, the durability and resistance to seawater conditions [59] and the effect of activator chemicals [60] have been of interest. 


\section{Methodology}

Our research methodology is illustrated in the flowchart presented in Figure 5.

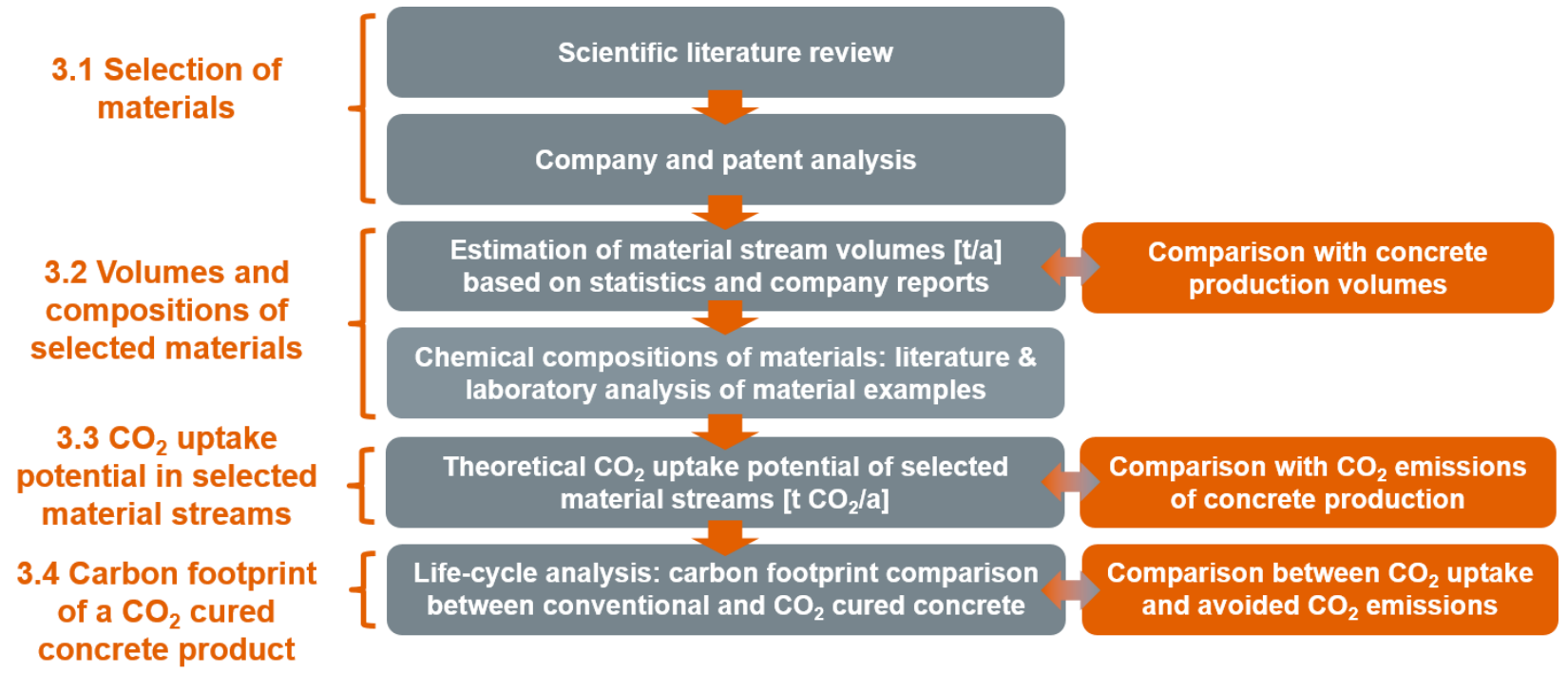

Figure 5 Research methodology flowchart. Each section is covered in more detail in the illustrated subchapters.

The alternative raw materials were selected, and their volumes were estimated based on the literature reports. The total volume was compared with the volume of concrete production to check if secondary raw material availability is a limiting factor. The $\mathrm{CO}_{2}$ uptake potentials were estimated using Steinour's and Huntzinger's formulae. In some cases, specific literature values were used. The total $\mathrm{CO}_{2}$ uptake potential was compared with the emission volume of the cement industry to see if the $\mathrm{CO}_{2}$ uptake potential is a limiting factor for emission reductions. It was also checked if the transportation of $\mathrm{CO}_{2}$ abroad for $\mathrm{CCS}$ could be avoided. The carbon footprints of $\mathrm{CO}_{2}$-cured concrete prepared using alternative binders and conventional concrete were compared and the difference between the $\mathrm{CO}_{2}$ uptake and $\mathrm{CO}_{2}$ emission reductions was highlighted. Finally, the impact of $\mathrm{CO}_{2}$ emission was studied under conditions of widespread implementation scenarios.

\subsection{Selection of Materials}

We required first to pre-select the materials that might have the maximum potential for $\mathrm{CO}_{2}-$ cured concrete applications. In a review on $\mathrm{CO}_{2}$-cured concrete [44], the studied materials included blast furnace and steel slags, cement kiln dust, waste cement, fossil fuel combustion ashes and municipal solid waste incineration ashes as well as serpentinite. In general, materials with high proportions of non-carbonate calcium and magnesium have shown the potential to bind significant amounts of $\mathrm{CO}_{2}$. For the Finnish case, the utilization of biomass combustion ashes and pulp mill wastes constituted the vital segments of wastes and these were also analyzed. In other countries, the size of each industry sector and the local geology (e.g., the availability of volcanic ashes or magnesium-containing minerals) play essential roles for material selection.

The materials that are already used in blended cement, like blast furnace slag and coal fly ash, are common to the industry and are included in the current cement standard SFS-EN 197-1 [33]. 
The use of these materials offer easier market penetration. A few companies have developed pilotscale processes using waste or byproduct streams employing the concept of $\mathrm{CO}_{2}$-cured concrete concepts $[52,54,61]$. The limited availability of these raw materials is a drawback of the process. The materials can be used for other carbon-footprint-lowering processes, such as the production of blended cement. The upcoming ban on coal combustion in Finland by 2029 [62] is going to further limit the availability of coal fly ash in Finland. Other materials may not be easily available in today's market, but their utilization is favorable for other reasons. The availability of the materials in large volumes can help the ambitions of the Finnish government toward achieving a circular economy.

\subsection{Volumes and Compositions of Selected Materials}

We sourced our data on waste materials by studying the statistics of wastes produced in Finland. We also studied the scientific literature, environmental permits, and annual and environmental reports published by selected major companies. A comprehensive view of the material volumes was gained by compiling field of industry report data and the individual material stream data. The chemical compositions of the explored materials were gathered from the literature except for biomass ashes and green liquor dregs, whose elemental compositions were determined in a commercial analysis laboratory using samples that were taken from a Finnish pulp mill.

We wanted to compare the waste material stream volumes, available in tons per year, with the volumes of the produced ready-mix and precast concrete in the same units. The annual production statistics available from the concrete industry are compiled on an $\mathrm{m}^{2}$-basis for concrete elementswalls and slabs. For the ready-mix concrete and blocks, the information is compiled on the $\mathrm{m}^{3}$-basis (Table 1) [13].

Table 1 Production of concrete products [13].

\begin{tabular}{lll}
\hline & Unit & Production amount \\
\hline Concrete elements & $\mathrm{m}^{2}$ & 873000 \\
Concrete panel shells & $\mathrm{m}^{2}$ & 275000 \\
Partition walls from concrete & $\mathrm{m}^{2}$ & 814000 \\
$\begin{array}{l}\text { Concrete slabs (incl. also Hollow core } \\
\text { slabs) }\end{array}$ & $\mathrm{m}^{2}$ & 3357000 \\
Ready-mix concrete & $\mathrm{m}^{3}$ & 2627000 \\
Concrete blocks & $\mathrm{m}^{3}$ & 92000 \\
\hline
\end{tabular}

The ready-mix concrete production in Finland (in tons) was then estimated using Equation 7. 


$$
\begin{gathered}
\text { Ready - mix concrete production in Finland }\left[\frac{t}{a}\right] \\
=\text { Cement used for ready }- \text { mix concrete }\left[\frac{t}{a}\right] \\
\text { /Estimated average cement content }[\mathrm{wt} \%] \\
\text { /Fraction of production covered by the statistic }[\mathrm{wt} \%] \\
=934000 t / a / 0.14 / 0.90=7412000 t / a \approx 7.4 \mathrm{Mt} / \mathrm{a}
\end{gathered}
$$

To determine the amount of precast concrete, Equation 8 was used.

$$
\begin{gathered}
\text { Precast concrete production in Finland }\left[\frac{t}{a}\right] \\
=\text { Cement used for precast concrete }\left[\frac{t}{a}\right] \\
\text { /Estimated average cement content }[\mathrm{wt} \%] \\
\text { /Fraction of production covered by the statistic }[\mathrm{wt} \%] \\
=479000 \mathrm{t} / \mathrm{a} / 0.14 / 0.90=3802000 \mathrm{t} / \mathrm{a} \approx 3.8 \mathrm{Mt} / \mathrm{a} .
\end{gathered}
$$

The concrete industry association of Finland estimates that their statistic covers about $90 \%$ of the concrete industry in Finland [13]. These amounts are only illustrative and to be used for reference only, as they are based on a rough estimation of the average cement content in concrete. In reality, concrete belonging to different strength classes contains different amounts of cement.

\section{3 $\mathrm{CO}_{2}$ Uptake Potential in Selected Material Streams}

The specific $\mathrm{CO}_{2}$ uptake potential values for different material streams were estimated using Steinour's formula (Equation 9) [63] and Huntzinger's formula (Equation 10) [64]. The values for recycled concrete and mine tailings were sourced from the literature.

$$
\begin{gathered}
\mathrm{CO}_{2} \text { uptake }[\%]=0.785\left(\mathrm{CaO}-0.7 \mathrm{SO}_{3}\right)+1.09 \mathrm{Na}_{2} \mathrm{O}+0.93 \mathrm{~K}_{2} \mathrm{O} \\
\qquad \mathrm{CO}_{2} \text { uptake }[\%] \\
=0.785\left(\mathrm{CaO}-0.56 \mathrm{Ca}(\mathrm{CO})_{3}-0.7 \mathrm{SO}_{3}\right) \\
+1.091 \mathrm{MgO}+0.71 \mathrm{Na}_{2} \mathrm{O}+0.468 \mathrm{~K}_{2} \mathrm{O}
\end{gathered}
$$

The $\mathrm{CO}_{2}$ uptake potential for the selected waste and byproduct streams was determined by multiplying the volumes with the specific $\mathrm{CO}_{2}$ uptake potentials (Equation 11).

$$
\begin{gathered}
\mathrm{CO}_{2} \text { uptake potential }\left[t \frac{\mathrm{CO}_{2}}{a}\right] \\
=\text { Volume of material produced }\left[\frac{t}{a}\right] \\
\text { * specific theoretical } \mathrm{CO}_{2} \text { uptake potential }\left[g \frac{\mathrm{CO}_{2}}{g} \text { material }\right]
\end{gathered}
$$

The $\mathrm{CO}_{2}$ uptake potentials were compared with the annual emissions from the cement industry in Finland (approximately $0.839 \mathrm{Mt} \mathrm{CO}_{2}$; Chapter 2.1). This provides a simple and reasonable comparison when the aim is to reduce and/or reuse the $\mathrm{CO}_{2}$ emissions from the cement industry. 


\subsection{Carbon Footprint of a $\mathrm{CO}_{2}$-Cured Concrete Product}

The life cycle assessment (LCA) method is used for assessing the carbon footprint of concrete products. The carbon footprint is defined as the sum of the greenhouse gas emissions and greenhouse gas removals in a product system and is expressed as $\mathrm{CO}_{2}$ equivalents $\left(\mathrm{CO}_{2} \mathrm{e}\right)$ based on an LCA under the conditions of a single impact category climate change [65].

The carbon footprint of the product is calculated and presented according to different stages in the life cycle: product stage (A1-3), construction (A4 and A5), use (B1-7), and end-of-life stage (C14) (Figure 6).

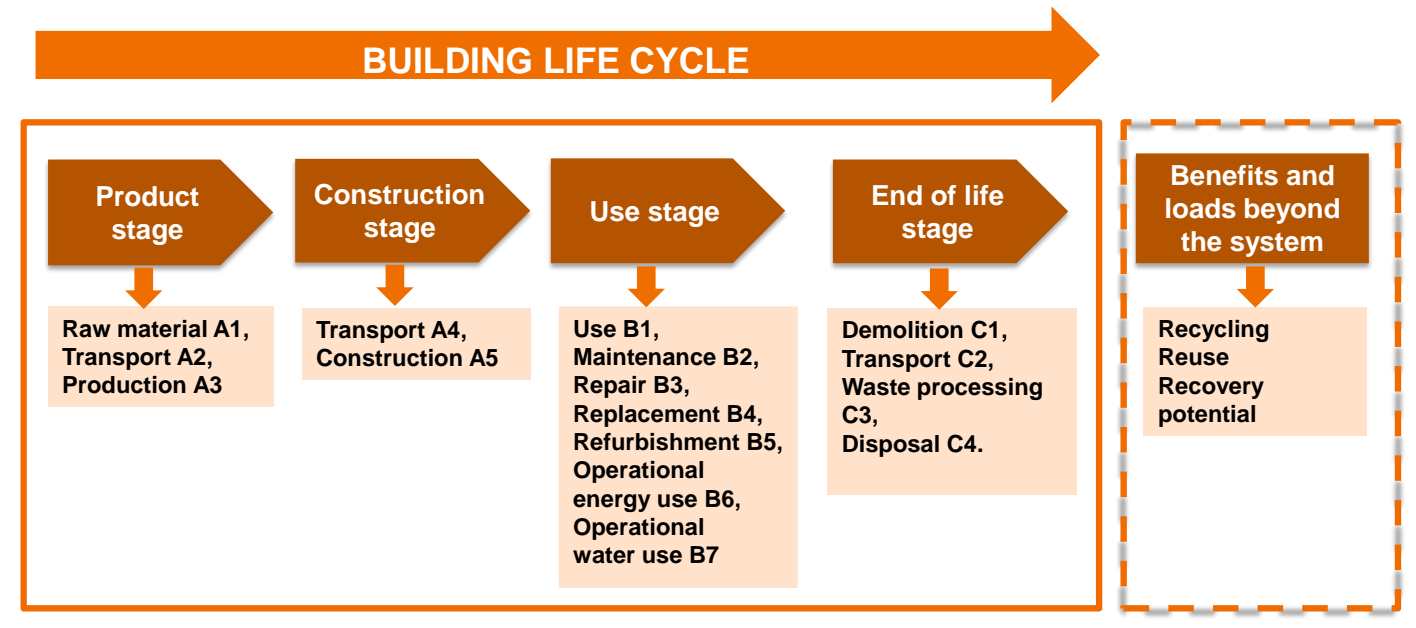

Figure 6 Stages of the life cycle for construction [66].

In this study, we have only assessed the product stage. We have studied A1 (raw materials), A2 (transportation), and A3 (manufacturing) (EN $15804+$ A1) stages because the research is focused on material development, and the full life cycle of data is missing.

The main ingredients required for the preparation of conventional concrete are cement, coarse and fine aggregates (such as sand, gravel, and crushed stone), additives (e.g., for air entrainment or plasticizing), and water. For reducing the use of cement, which significantly influences $\mathrm{CO}_{2}$ emissions, concrete mix is blended (with silica, ground blast furnace slag, or coal combustion fly ash). The reduction in emission is based on the LCA process, where the emission due to material production is allocated to the main product and the waste user gets the waste without allocated emissions from the main product manufacturing. When waste material reaches the end-of-waste state (EoW), it can be categorized as a product. Impact allocations between the main and waste product should be used for the studies. However, according to EN 15804, EoW is reached when the material that is commonly used fulfills the technical requirements and legislation. Its use will not lead to adverse environmental or human health impacts andthere is significant market demand.

In our assessment, most side streams, with the exceptions of blast furnace slag and purified $\mathrm{CO}_{2}$, are without allocated emissions and are considered as wastes. If they are considered as byproducts, a small share of emissions can be potentially allocated to them. However, the main product gets the main share. Blast furnace steel slag is a byproduct of the steelmaking industry, and thus, allocation is done (slag $42 \mathrm{~kg} \mathrm{CO}_{2} / \mathrm{t}$ vs. steel $2100 \mathrm{~kg} \mathrm{CO} / \mathrm{t}$ ). The examples of the raw material shares of a conventional concrete hollow core slab are shown in Figure 3. 
Each type of concrete is designed for specific use and must meet specific material requirements (such as compressive strength). The material requirements affect the concrete composition (i.e., the share of cement), which affects the carbon footprint of the product. Example compositions of concretes of different strength classes C16/20, C12/15, and C8/10, based on an earlier study [67], are presented in Table 2 to illustrate these interdependencies.

Table 2 Concrete mix design and carbon footprint of concrete for OPC strength classes $\mathrm{C} 16 / 20, \mathrm{C} 12 / 15$, and C8/10 based on an earlier study [67] and a modeled mix for the preparation of $\mathrm{CO}_{2}$-cured concrete using blast furnace slags.

\begin{tabular}{|c|c|c|c|c|c|c|}
\hline & Unit & C16/20 & $\mathrm{C} 12 / 15$ & $\mathrm{C} 8 / 10$ & $\begin{array}{l}\mathrm{CO}_{2} \text {-cured } \\
\text { concrete }\end{array}$ & $\begin{array}{l}\text { Unit impact and data } \\
\text { source, } \mathrm{gCO}_{2} \mathrm{e} / \mathrm{kg} \\
\text { (Life cycle stage } \mathrm{A} 1-3 \text { ) }\end{array}$ \\
\hline Plus-cement & $\mathrm{kg} / \mathrm{m}^{3}$ & $\begin{array}{l}300 \\
(13 w t \%)\end{array}$ & $\begin{array}{l}260 \\
(11 \mathrm{wt} \%)\end{array}$ & $\begin{array}{l}210 \\
(9 \\
w t \%)\end{array}$ & - & 702 [68] \\
\hline $\begin{array}{l}\text { Crushed stone } \\
8 / 16 \mathrm{~mm}\end{array}$ & $\mathrm{~kg} / \mathrm{m}^{3}$ & 1100 & 1100 & 1110 & - & 13.9 [69] \\
\hline Sand $0 / 8 \mathrm{~mm}$ & $\mathrm{~kg} / \mathrm{m}^{3}$ & 740 & 790 & 860 & - & 2.4 [69] \\
\hline Water & $\mathrm{kg} / \mathrm{m}^{3}$ & 140 & 130 & 120 & 140 & $0.276[69]$ \\
\hline $\begin{array}{l}\text { Blast furnace slag } \\
\text { (granulated) }\end{array}$ & $\mathrm{kg} / \mathrm{m}^{3}$ & - & - & - & 2140 & $42[10]$ \\
\hline $\begin{array}{l}\text { Case A: Pure } \mathrm{CO}_{2} \\
(100 \mathrm{wt} \%)\end{array}$ & $\mathrm{kg} / \mathrm{m}^{3}$ & - & - & - & 300 & $76 *$ \\
\hline $\begin{array}{l}\text { Case B: } \\
\text { compressed flue } \\
\text { gas } \mathrm{CO}_{2} \text { (40 wt\%) }\end{array}$ & $\mathrm{kg} / \mathrm{m}^{3}$ & - & - & - & $300 \times 2.5$ & $18.1 * *$ \\
\hline $\begin{array}{l}\text { Case C: Flue gas as } \\
\text { such } \mathrm{CO}_{2}(40 \mathrm{wt} \%)\end{array}$ & $\mathrm{kg} / \mathrm{m}^{3}$ & - & - & - & $300 \times 2.5$ & $\begin{array}{l}0 \text { (assumption: flue gas } \\
\text { as such) }\end{array}$ \\
\hline Finnish Electricity & $\mathrm{kWh} / \mathrm{m}^{3}$ & 20 & 20 & 20 & 200 & $\begin{array}{l}0.109 \mathrm{~kg} / \mathrm{kWh} \text { (average } \\
\text { Finnish electricity) } * * *\end{array}$ \\
\hline
\end{tabular}

* Calculated according to the Linde-engineering process and specific energy demand of $2.5 \mathrm{GJ} / \mathrm{t}$ $\mathrm{CO}_{2}$ regenerated [70]. It is assumed that the energy type for $\mathrm{CO}_{2}$ capture is electricity and the $\mathrm{CO}_{2}$ emission recorded is the average Finnish electricity.

** Calculated value, flue gas ( 40 wt.\% $\mathrm{CO}_{2}$ ) compressed to 1 bar of $\mathrm{CO}_{2}$ pressure; compression electricity: $171.6 \mathrm{~kJ} / \mathrm{kg}$ flue gas.

*** Delivered electricity calculated using VTT's Sustainability tool (SULCA) [71] and Finnish average Electricity production data, based on the energy data for the year 2018 [72]. 
In addition, Table 2 also presents a hypothetical blast furnace slag block mix design for $\mathrm{CO}_{2}$ curing . This case is calculated for different sources of $\mathrm{CO}_{2}$ : purified $\mathrm{CO}_{2}$ (Case $A$ ), $\mathrm{CO}_{2}$ from compressed flue gas (Case $\mathrm{B}$ ), and $\mathrm{CO}_{2}$ from flue gas (Case $\mathrm{C}$ ).

The carbon footprint of the class $\mathrm{C} 16 / 20$ concrete is $43 \%$ higher than that of class $\mathrm{C} 8 / 10$. A comparative assessment between conventional and $\mathrm{CO}_{2}$-cured concretes was carried out. The concretes in the strength class $\mathrm{C} 16 / 20$ were chosen for comparison because based on experiments published in a patent, this strength class is also achievable with $\mathrm{CO}_{2}$-cured alternative binder concrete [73]. In addition, the carbon footprints of a few conventional concrete products were calculated to gain a better understanding of the range of carbon footprints of the current concrete products.

In this study, we compared a conventional concrete block with a modeled $\mathrm{CO}_{2}$-cured blast furnace slag block. The blast furnace slags were sourced from the Raahe Steel mill, and the blocks were produced following a similar process as piloted in Belgium [74]. The process can be followed to bind 0.30 tons of $\mathrm{CO}_{2}$ per every $\mathrm{m}^{3}$ of concrete block produced. The method causes 0.08 tons of $\mathrm{CO}_{2} / \mathrm{m}^{3}$ of product (energy demand: $200 \mathrm{kWh} / \mathrm{m}^{3}$ product). In our assessment, we use the stated energy demand and the average emission intensity of electricity production in Finland $0.109 \mathrm{~kg}$ $\mathrm{CO}_{2} / \mathrm{kWh}$; delivered electricity in 2018, calculated using SULCA [71] based on [72]).

In both cases, we assumed that the concrete blocks are produced in Raahe, Finland. The cement factory is located in Parainen. Industrially separated, purified, and compressed $\mathrm{CO}_{2}$ is produced at the Kilpilahti oil refinery in Porvoo [75]. Waste $\mathrm{CO}_{2}$ was available at the flue gas of the on-site lime kiln at the Raahe steel mill [76]. However, the $\mathrm{CO}_{2}$ concentration of the lime kiln flue gas is assumed to be approximately $40 \mathrm{wt}$.\% ([77]; first combustion with no re-circulation). Thus, 2.5 times the $\mathrm{CO}_{2-}$ containing gas is needed for the completion of the process in comparison to $99.8 \%$ of pure $\mathrm{CO}_{2}$ [78] from Porvoo. The flue gas could be used as such or dried and compressed. The assumed transportation distances of raw materials are presented in Table 3.

Table 3 Estimated raw material transportation distances.

\begin{tabular}{|c|c|c|c|c|}
\hline & $\begin{array}{l}\text { Reference } \\
\text { case: } \\
\text { Conventional } \\
\text { concrete }\end{array}$ & $\begin{array}{l}\text { Case } \mathrm{A} \text { : } \\
\mathrm{CO}_{2} \text {-cured } \\
\text { blast furnace } \\
\text { slag } \quad(99.8 \% \\
\left.\mathrm{CO}_{2}\right)\end{array}$ & $\begin{array}{l}\text { Case B: } \\
\text { Compressed } \\
\text { flue gas }(40 \\
\left.\text { wt\% } \mathrm{CO}_{2}\right) \text { cured } \\
\text { blast furnace } \\
\text { slag }\end{array}$ & $\begin{array}{l}\text { Case C: } \\
\text { Non- } \\
\text { compressed } \\
\text { flue gas ( } 40 \\
\left.\text { wt\% } \mathrm{CO}_{2}\right) \text { cured } \\
\text { blast furnace } \\
\text { slag }\end{array}$ \\
\hline Plus-cement & 597 km & - & - & - \\
\hline Crushed stone $8 / 16 \mathrm{~mm}$ & $50 \mathrm{~km}$ & - & - & - \\
\hline Sand $0 / 8 \mathrm{~mm}$ & $50 \mathrm{~km}$ & - & - & - \\
\hline $\begin{array}{l}\text { Granulated blast furnace } \\
\text { slag }\end{array}$ & $1 \mathrm{~km}$ & $1 \mathrm{~km}$ & $1 \mathrm{~km}$ & $1 \mathrm{~km}$ \\
\hline Additive & $100 \mathrm{~km}$ & - & - & - \\
\hline $99.8 \% \mathrm{CO}_{2}$ & - & $581 \mathrm{~km}$ & - & - \\
\hline Flue gas (40 wt $\% \mathrm{CO}_{2}$ ) & - & - & $1 \mathrm{~km}$ & $1 \mathrm{~km}$ \\
\hline
\end{tabular}


It is more appropriate to use bottled and purified $\mathrm{CO}_{2}$ during the piloting stage of a process. In large-scale production, the availability of on-site high-concentration $\mathrm{CO}_{2}$ waste gas is assumed to bring major benefits. The aspect of $\mathrm{CO}_{2}$ source, as well as the following major parameters and their influence on the production of carbon footprint, are explored using a sensitivity analysis method:

- the emission intensity of the $\mathrm{CO}_{2}$ used

- transportation distance of the used binder material

- the emission intensity of the used electricity

- $\mathrm{CO}_{2}$ uptake ability of the material

The transportation distance changes if the concrete block production was planned at a site far from the Raahe steel mill. The emission intensity of electricity could change in Finland over time. It can also change if the concrete producer had a specific electricity purchase agreement or own power production. The $\mathrm{CO}_{2}$ uptake could change based on the additives used, process conditions, and the use of different raw materials.

\section{Results and Discussion}

We have studied the $\mathrm{CO}_{2}$ emission reduction potential of $\mathrm{CO}_{2}$-cured alternative binder concrete using the case of Finland as an example. Our research questions were as follows:

- What kind of material streams could be suitable for large-scale, $\mathrm{CO}_{2}$-cured concrete applications in Finland? (Chapter 4.1)

- How big are the volumes in which those material streams are available in Finland? (Chapter 4.1)

- What is the $\mathrm{CO}_{2}$ uptake potential in the selected material streams? (Chapter 4.2)

- How does the carbon footprint of a modeled $\mathrm{CO}_{2}$-cured blast furnace slag block compare with that of a conventional concrete block? (Chapter 4.3)

Based on the obtained results, we discuss the role of the $\mathrm{CO}_{2}$-cured alternative binder concrete in emission reductions in Finland (Chapter 4.4).

\subsection{Volumes of Material Streams Potentially Suitable for $\mathrm{CO}_{2}$-Cured Concrete}

Based on the results presented in the literature, patent, and company analysis reports, we chose different types of ashes, green liquor dregs, blast furnace, and steel slags, crushed concrete, mine tailings, and foundry sands for further analysis. The total volume of these material streams was approximately $27 \mathrm{Mt} / \mathrm{a}$. The maximum volume was attributed to the mine tailings, an unutilized waste material stream (volume: $23 \mathrm{Mt}$ in the year 2017 in Finland) [79]. Blast furnace and steelmaking slags, with a combined annual production volume of approximately $1.8 \mathrm{Mt}$, also contribute significantly to the material stream. Recycled concrete with an annual production of 1 Mt can also be used to substitute virgin raw materials and different kinds of ashes produced during the process of energy production and waste incineration. They have a combined volume of $1.2 \mathrm{Mt} / \mathrm{a}$. The combined volume of potential waste streams for $\mathrm{CO}_{2}$-cured concrete applications is higher than the volume of the binder used (479000 t/a) during the process of precast concrete production (Figure 7). 


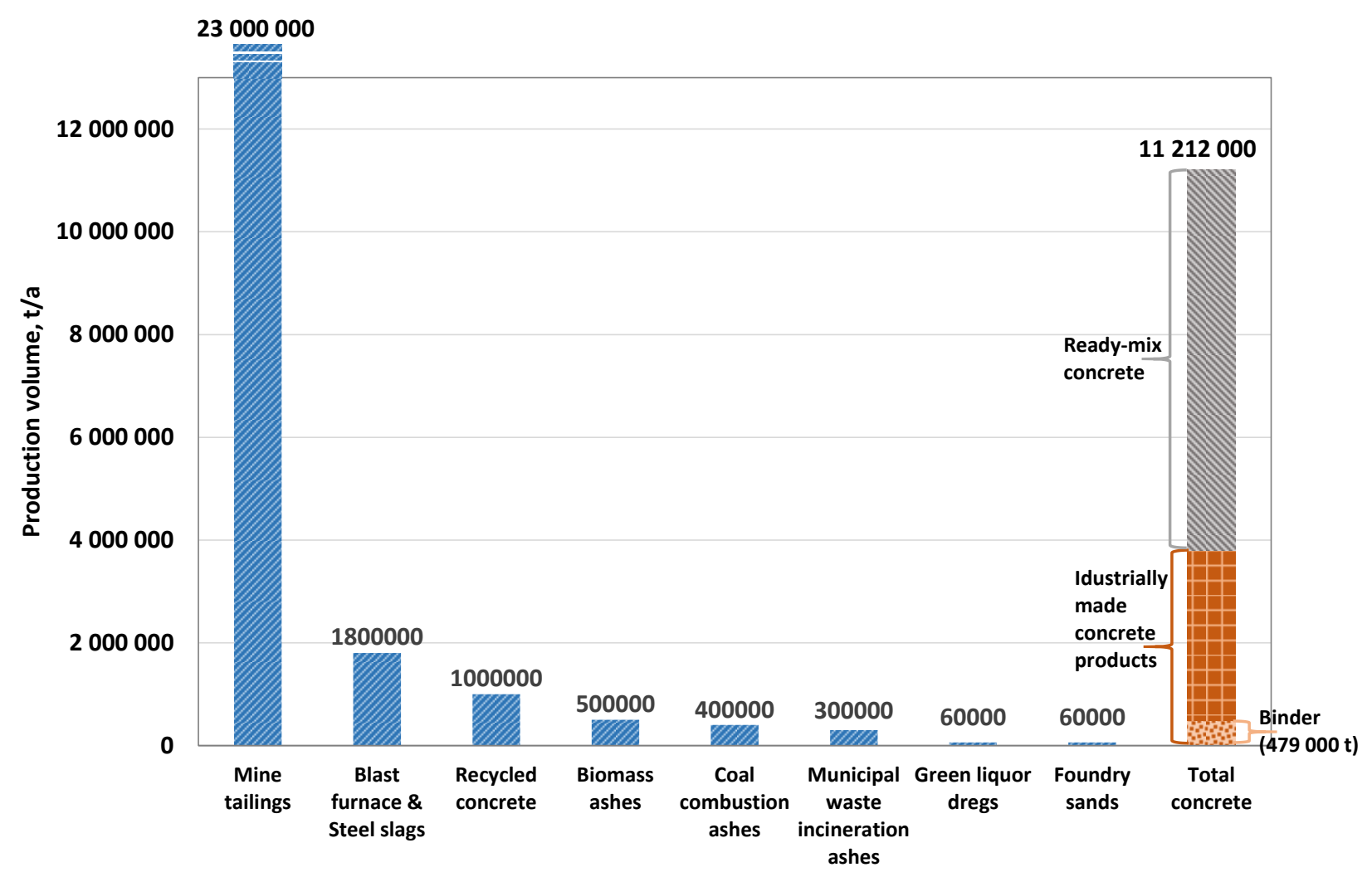

Figure 7 Volumes of selected wastes and byproduct streams produced annually in Finland.

Mine tailings are a group of materials with different mineralogical and chemical compositions. These are primarily stored in the form of slurry in impounding basins [80]. Inert tailings are typically used as construction materials at mining sites. They are also used for road construction. They can also be used as backfill and dam support materials [81]. Even if the inert tailings could not function as a binder in $\mathrm{CO}_{2}$ cured concrete, the ease in availability is important for constructing a circular economy-based concrete production. These could be used as a substitute for virgin aggregates. A part of the mine tailings can react and act as binders (such as serpentinite containing mine tailings). These are found in Finland, for example at the site of the Hitura mine in the region of Northern Ostrobothnia. These can also be found at the Outokumpu mine in the region of North Karelia [82]. We estimated that the amount of binder-suitable mine tailings was approximately $10 \%$ or $2.3 \mathrm{Mt} / \mathrm{a}$. In addition to mine tailings in operating and closed mines, such minerals are found in large amounts in the virgin rock of Finland. The storage capacity is in the range of 2000-3000 Mt $\mathrm{CO}_{2}$ [83]. It will be a great benefit to have such a reserve if the $\mathrm{CO}_{2}$ emission allowance price rises high enough to drive the extra-production for the sake of $\mathrm{CO}_{2}$ capture.

Blast furnace slags and steel slags are mainly classified as byproducts and have a utilization degree of up to $90-100 \%$. According to the Environmental report of Finnsementti [6], 95000 tons of blast furnace slag was used for producing cement in Finland (2017) together with other waste materials, such as coal fly ash, nickel slag, and rolled sludge. Slag products can also replace virgin materials in road construction or be used as fertilizers. However, if less than 100000 tons of the 1 800000 tons is currently used for producing cement, it might be worthwhile to re-evaluate the use of those raw materials. 
Crushed concrete wastes, especially fines, are difficult to utilize currently. Yet they are produced in large amounts, in close collaboration with the industry producing new concrete. This can also lower the transportation costs when the distances are less. In Finland, crushed concrete is currently utilized for secondary earth construction applications. Refining processes have become more common, and products with higher quality are produced. There is also a growing interest in using crushed concrete as recycled aggregates in the production of concrete. Finely crushed concrete can absorb $\mathrm{CO}_{2}$ from the atmosphere if good contact is allowed with ambient air for decades. Similar to laboratory experiments, when finely crushed recycled concrete is used as a raw material for the production of $\mathrm{CO}_{2}$-cured concrete, accelerated carbonation proceeds in a matter of hours. The carbonation potential is utilized in full without the limitations of the sub-optimal conditions (passive open-air carbonation). The speed of the process is a significant benefit considering the urgency of the deep greenhouse gas emission cuts.

Ashes constitute a thermally-activated material stream, but traces from harmful substances and variation in the composition may bring challenges. For ashes produced during biomass combustion, the sulfuric compounds may cause expansion and cracking in steel-reinforced concrete structures [84]. $\mathrm{CO}_{2}$ curing may change this, however, allowing the materials to expand more rapidly under aggressive conditions. The maximal volume can potentially be reached prior to full-strength development. The current utilization degree of ashes in Finland is estimated to be $70-80 \%$. Nevertheless, in most cases, ashes have a low or negative value. Coal fly ashes, with an acceptable quality level, are utilized in cement production or as binder materials in concrete applications and fillers in asphalt. Biomass ashes that fulfill the criteria of national fertilizer legislation can be used as fertilizer products in the fields of agriculture or forestry. These above-mentioned utilization options cover only about $25 \%$ of the total ash amount, and roughly $50 \%$ is used in earth construction. The final $25 \%$ is landfilled. The volume of coal ashes is decreasing rapidly and will be zero in ten years. The amount of biomass ashes is expected to increase. Increasing energy utilization of waste has increased the amount of waste derived from ashes. However, it is difficult to predict how the circular economy and targets set for material recycling will affect the ash amounts in the future.

Green liquor dregs (GLD) are currently landfilled. The utilization options are being intensively researched. GLD contains nutrients that could be utilized as or in fertilizer products. According to its role in removing non-process elements from the chemical recovery process of a pulp mill, it also contains metals that can be harmful to the environment. It has also been proposed that the mineral content of GLD could be used in construction products. Further research should be conducted to verify the potential of GLD in this application. The composition of GLD differs from one pulp mill to another, and sometimes it also contains a remarkable amount of lime mud that is used as a precoat in the washing and dewatering processes. These quality variations may cause challenges in utilization. The elevated concentrations of calcium and magnesium in GLD could promote $\mathrm{CO}_{2}$ binding.

Waste foundry sands have usually been landfilled, but the tightening of the legislation has forced the producers to search for utilization options. Foundry sands can be used in certain earth construction applications by a notification procedure if the requirements of the Government Decree on the Recovery of certain wastes in Earth Construction (843/2017) [85] are fulfilled. Most of the waste foundry sands exceed the leaching limit values of the decree, and an environmental permit is needed for their utilization in earth construction applications. The utilization of foundry sands as aggregates in concrete production, raw material in mineral wool production, bed sand in energy 
production by fluidized bed boilers, and structuring material in composting have also been researched [86].

\subsection{Compositions and Specific $\mathrm{CO}_{2}$ Uptake Potentials of Selected Materials}

The materials used in this study and the sources of their constituents (Table 4) are described as follows:

1. Blast furnace slag is formed when iron ore or iron pellets, coke, and flux (limestone or dolomite) are melted together in a blast furnace [87].

2. Electric arc furnace slag is a byproduct of the steelmaking process in electric arc furnaces [88].

3. Basic oxygen furnace slag is a byproduct of the steelmaking process in a wholly integrated steel mill [88].

4. Bark fly ash 1 is separated from the flue gases of the bark-fuelled boiler (the composition of a fly ash sample from a bark-fuelled $104 \mathrm{MW}$ bubbling fluidized bed boiler was determined in a commercial analysis laboratory using the X-ray fluorescence technique).

5. Bark fly ash 2 (50\% of the analyzed calcium content of bark fly ash 1 was assumed to exist as carbonate $\left(\mathrm{CaCO}_{3}\right)$ and $50 \%$ as oxide $\left.(\mathrm{CaO})\right)$.

6. Green liquor dregs originate from the chemical recovery cycle of the kraft wood pulp production process, where sodium hydroxide and sodium sulfide are effectively regenerated from black liquor (Composition of a green liquor dreg sample was determined in a commercial analysis laboratory by the ICP-OES technique (waste characterization EN 13656)).

7. Recycled concrete $\left(\mathrm{CO}_{2}\right.$ uptake potential from literature (Fang et al., 2017 [89]; maximum value)).

8. Coal fly ash, bituminous [90].

9. Municipal solid waste incineration (MSWI) bottom ash [91]; Mixture of MSWI fly ash and air pollution control residues (APC) [92].

10. Foundry sand is silica sand that has been used in foundry casting processes [93].

11. Mine tailings ( $\mathrm{CO}_{2}$ uptake potential from the literature [94]).

The material stream compositions and specific $\mathrm{CO}_{2}$ uptake potential values calculated using Steinour's and Huntzinger's formulae are presented in Table 4. 
Table 4 Composition and specific $\mathrm{CO}_{2}$ uptake potential of selected materials.

\begin{tabular}{|c|c|c|c|c|c|c|c|c|c|}
\hline & $\mathrm{CaO}$ & $\mathrm{CaCO}_{3}$ & MgO & $\mathrm{Na}_{2} \mathrm{O}$ & $\mathrm{K}_{2} \mathrm{O}$ & $\mathrm{SO}_{3}$ & $\begin{array}{l}\text { Steinour } \\
{\left[\mathrm{t} \mathrm{CO}_{2} / \mathrm{t} \text { material] }\right.}\end{array}$ & $\begin{array}{l}\text { Huntzinger } \\
{\left[\mathrm{t} \mathrm{CO}_{2} / \mathrm{t} \text { material] }\right.}\end{array}$ & $\begin{array}{l}\text { Literature } \\
{\left[\mathrm{t} \mathrm{CO}_{2} / \mathrm{t} \text { material }\right]}\end{array}$ \\
\hline $\begin{array}{l}\text { Blast furnace } \\
\text { slag }\end{array}$ & 42.3 & 0 & 7.86 & 0.62 & 0.61 & 2.54 & 0.33 & 0.41 & \\
\hline EAF slag & 47.52 & 0 & 7.35 & 0.06 & 0.02 & 2.28 & 0.36 & 0.44 & \\
\hline BOF slag & 39.4 & 0 & 9.69 & 0.25 & 0.05 & 0.12 & 0.31 & 0.42 & \\
\hline Bark fly ash 1 & 17.35 & 0 & 2.37 & 2.88 & 5.72 & 8.21 & 0.18 & 0.16 & \\
\hline Bark fly ash 2 & 8.68 & 8.68 & 2.37 & 2.88 & 5.72 & 8.21 & 0.11 & 0.06 & \\
\hline $\begin{array}{l}\text { Green liquor } \\
\text { dregs }\end{array}$ & 1.63 & 40.79 & 15.90 & 2.67 & 0.17 & 7.79 & 0.08 & 0.01 & \\
\hline $\begin{array}{l}\text { Recycled } \\
\text { concrete }\end{array}$ & & & & & & & & & 0.04 \\
\hline $\begin{array}{l}\text { Coal fly ash } \\
\text { (bituminous) }\end{array}$ & 3.92 & 0 & 1.75 & 0.87 & 2.77 & 3.34 & 0.05 & 0.05 & \\
\hline \multicolumn{10}{|l|}{ MSWI: } \\
\hline Bottom ash & 16.3 & 0 & 2.6 & 6.0 & 1.10 & 7.49 & 0.16 & 0.16 & \\
\hline Fly ash + APC & 36.27 & & & & 2.04 & & 0.30 & 0.29 & \\
\hline Foundry sand & 0.14 & 0 & 0.3 & 0.19 & 0.25 & 0.09 & 0.01 & 0.01 & \\
\hline Mine tailings & & & & & & & & & ? \\
\hline Serpentinite & & & & & & & & & 0.40 \\
\hline
\end{tabular}


The estimated specific $\mathrm{CO}_{2}$ uptake potential of steel and blast furnace slags, municipal waste incineration ashes, biomass fly ashes, bituminous coal fly ashes, and green liquor dregs were approximately 30-45, 15-30, 5-20, about 5, and 1-10 g CO 2 /g binder, respectively. The '?' for mine tailings indicates that the mineral composition and $\mathrm{CO}_{2}$ uptake potential vary greatly between different tailings. Some tailings, such as those obtained in the Hitura mine containing serpentinite, are known to be effective [82].

The total annual $\mathrm{CO}_{2}$ uptake potential of the selected Finnish waste and byproduct streams was estimated (Figure 8). It was assumed that $10 \mathrm{wt} . \%$ of mine tailings and all other selected material streams were available for $\mathrm{CO}_{2}$ binding.

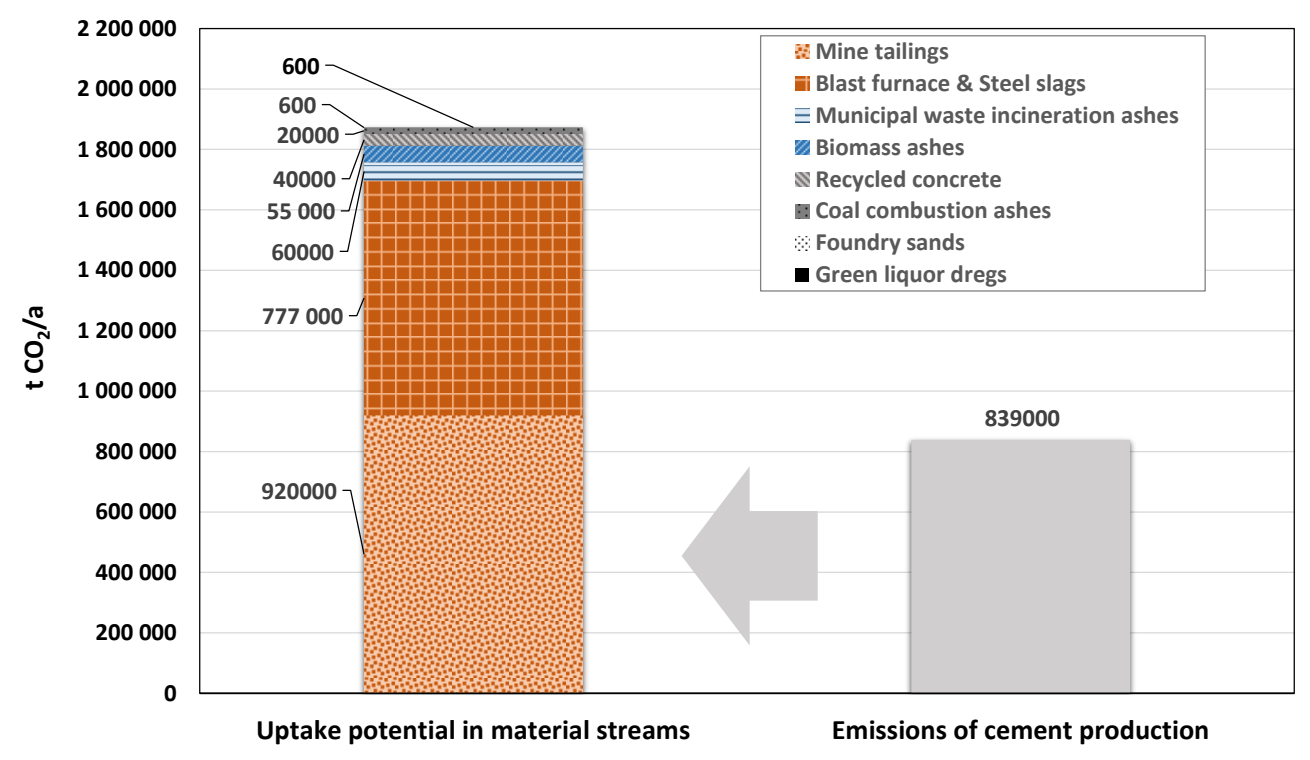

Figure $8 \mathrm{Annual} \mathrm{CO}_{2}$ uptake potential in selected waste and byproduct streams. The total $\mathrm{CO}_{2}$ uptake potential is large enough to bind the $\mathrm{CO}_{2}$ emissions of all cement production in Finland.

This estimated total annual $\mathrm{CO}_{2}$ uptake potential was $1.9 \mathrm{Mt}$, which was 2.3 times the annual emission from the cement production in Finland. If a significant part of this $\mathrm{CO}_{2}$ uptake potential was available for binding the $\mathrm{CO}_{2}$ produced by the current cement industry, there would be no need for CCS abroad. The highest annual $\mathrm{CO}_{2}$ uptake potential is exhibited by mine tailings $(0.92 \mathrm{Mt})$, followed by blast furnace and steel slags $(0.78 \mathrm{Mt})$, municipal waste incineration ashes (0.06 Mt), and biomass ashes $(0.055 \mathrm{Mt})$. Other material streams exert a less significant effect on the annual uptake potential of $\mathrm{CO}_{2}$.

There can be large quality variations within waste and byproduct material streams that may hinder their utilization in concrete products. For example, there is a lot of variation in ash compositions resulting from different fuels, combustion technology, process parameters, flue gas cleaning system, and possible additives that are used for controlling fouling and corrosion. The $\mathrm{CO}_{2}$ uptake potential of recycled concrete aggregates is highly dependent on the cement content, the particle size of aggregates, and $\mathrm{CO}_{2}$ uptake of the previous lifetime. Waste materials can also include harmful elements or substances (e.g., heavy metals or salts) that may limit their use in concrete 
applications. These possible health, safety, and environmental effects have not been accounted for in this study. Another limiting factor is not all the concrete products $\left(\mathrm{CO}_{2}\right.$-cured alternative binder) can be applied at an industrial level. For instance, by controlling the $\mathrm{CO}_{2}$ uptake to a certain level by tuning the curing time and $\mathrm{CO}_{2}$ pressure, the $\mathrm{pH}$ level could be retained at a safe level of 9.5 or higher [15] to protect steel reinforcements. Thus, these can be used for the preparation of various precast concrete products.

Although a huge $\mathrm{CO}_{2}$ uptake potential is exhibited by wastes and byproducts, the same materials can also be used as cheap raw materials for other uses. For example, the most important elements that affect the $\mathrm{CO}_{2}$ binding capacity of material are $\mathrm{Ca}, \mathrm{Mg}$, and $\mathrm{K}$, the same elements that are also essential for preparing fertilizer products. Moreover, ashes and slags are used as alternatives for natural gravel and sand in different construction and civil engineering applications. The maximum added value will dictate the uses in the future.

\subsection{Carbon Footprint of Conventional and $\mathrm{CO}_{2}$-Cured Alternative Binder Concrete}

Concrete is used in different fields, requiring different mix designs. It also results in different carbon footprints. The raw material compositions used in our analyses for conventional and $\mathrm{CO}_{2}-$ cured concrete are summarized in Table 2 and Figure 3. The carbon footprints of conventional concrete in strength classes $\mathrm{C} 16 / 20, \mathrm{C} 12 / 15$, and $\mathrm{C} 8 / 10$ and for a hollow core slab (HCS) are presented in Figure 1.

As can be seen, the carbon footprints of conventional concrete varied from 179 to $244 \mathrm{~kg} / \mathrm{m}^{3}$, and the main $\mathrm{CO}_{2}$ impact is related to cement use. It constituted approximately $82-86 \%$ of the total impact in these products. This highlights the importance of selecting the right concrete based on material requirements. For example, if class $\mathrm{C} 16 / 20$ concrete is used, where class $\mathrm{C} 8 / 10$ concrete would suffice, the carbon footprint would already be $36 \%$ higher.

Figures $9 \mathrm{a}$ and $9 \mathrm{~b}$ show the carbon footprint assessment results for the ordinary concrete block (OPC with strength class $\mathrm{C} 16 / 20$ ) and a $\mathrm{CO}_{2}$-cured concrete block (Case $\mathrm{A}$ ), which is made of blast furnace slag (Table 2). For the $\mathrm{CO}_{2}$-cured concrete (Case $\mathrm{A}$ ), purified $\mathrm{CO}_{2}$ is acquired from Porvoo and presumably produced following the Linde process.

In Figure 9a, the $\mathrm{CO}_{2} \mathrm{e}$ impact is presented for life cycle stages A1-3 (raw-material production, transport, and concrete production). The results reveal that the $\mathrm{CO}_{2}$ curing process $\left(\mathrm{CO}_{2}\right.$ uptake + $\mathrm{CO}_{2}$-caused from the life cycle stage $\mathrm{A} 3$ ) has a carbon-negative impact of $-278 \mathrm{~kg} \mathrm{CO} / \mathrm{m}^{3}$, while the impact from raw material production and transportation ( $\mathrm{A} 2$ and $\mathrm{A} 3$ ) in total is $+122 \mathrm{~kg} \mathrm{CO} \mathrm{e}_{2} / \mathrm{m}^{3}$ (Figure 9a). The net carbon footprint for life cycle stages $A 1-3$ of the studied materials is presented in Figure 9b. 

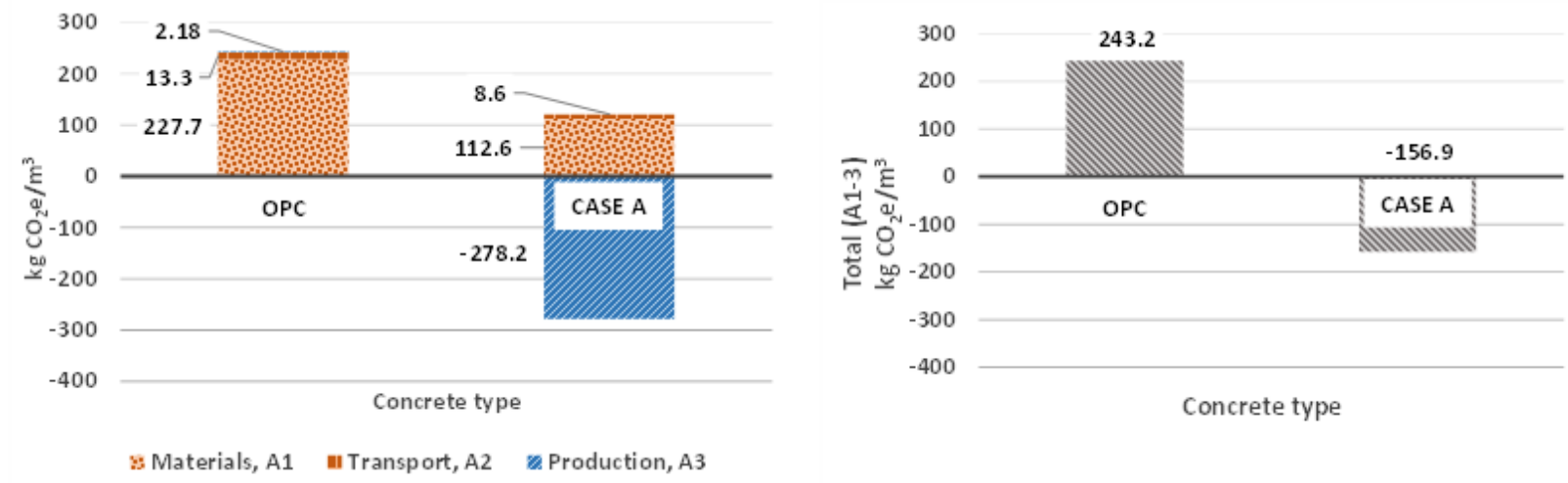

Figure $9 \mathrm{a}$ (left) and $\mathrm{b}$ (right). Carbon footprint $\left(\mathrm{kg} \mathrm{CO} \mathrm{CO}_{2} \mathrm{e} / \mathrm{m} 3\right)$ for the concrete $(\mathrm{OPC} / \mathrm{C} 16 / 20)$ and the $\mathrm{CO}_{2}$-cured concrete (Case $\mathrm{A}$, made from slag and cured with purified $\mathrm{CO}_{2}$ ). The individual carbon footprint for the life cycle stages $\mathrm{A} 1-3$ (9a) and net carbon footprint for the life cycle stages A1-3 (9b).

In total, the carbon footprint of the carbon-cured concrete still remains carbon negative, $(-278+$ $122=)-157 \mathrm{~kg} \mathrm{CO} 2 \mathrm{e} / \mathrm{m}^{3}$. The production of $\mathrm{CO}_{2}$-cured blast furnace slag concrete, instead of OPC production, would lead to $\mathrm{CO}_{2}$ savings over the life cycle stage A1-3. When the impacts from OPC production and impacts from $\mathrm{CO}_{2}$-cured concrete production are avoided, it totals ( - $243-157=$ ) $400 \mathrm{~kg} \mathrm{CO}_{2}$ e per every $\mathrm{m}^{3}$ of concrete produced (Figure $9 \mathrm{~b}$ ).

A sensitivity analysis of the carbon footprint of OPC (C 16/20) and $\mathrm{CO}_{2}$-cured concrete (Case A) is made (the assessment considers life cycle stages $A 1-3$ ):

$\mathrm{CO}_{2}$ uptake of the $\mathrm{CO}_{2}$-cured concrete is presented in Figure $10\left(20 \mathrm{~kg} \ldots 300 \mathrm{~kg} \mathrm{CO} / \mathrm{m}^{3}\right)$ (OPC carbonation during the service life is not considered, as this process does not happen during the concrete production),

- The transportation distance of binder material is presented in Figure $11(1 \mathrm{~km} . .1500$ $\mathrm{km})$,

- Carbon intensity for electricity production is presented in Figure $12\left(10 \mathrm{~g} \mathrm{CO}_{2} \mathrm{e} / \mathrm{kWh}\right.$ (wind power) ... $1000 \mathrm{~g} \mathrm{CO}_{2} \mathrm{e} / \mathrm{kWh}$ (coal-based electricity)

in Figure 13:

Emission intensity for the $\mathrm{CO}_{2}$ source used during the $\mathrm{CO}_{2}$ curing process is presented

Case A-purified (99.8\%) bottled $\mathrm{CO}_{2}$ from Porvoo/Linde process and concrete production in Nordkalk/Raahe,

Case B-compressed flue gas from Nordkalk Raahe, concrete production in Nordkalk/Raahe (for ensuring the same $\mathrm{CO}_{2}$ amount as that used in Case $\mathrm{A}$, the volume of $\mathrm{CO}_{2}$ containing flue gas was 2.5 times that of the volume presented in Case $A$ ),

C Case C-flue gas obtained from Nordkalk/Raahe, concrete production in Nordkalk/Raahe (for ensuring the same $\mathrm{CO}_{2}$ amount used in Case $\mathrm{A}, \mathrm{CO}_{2}$ containing flue gas volume was 2.5 times that of the volume used in Case $A$ ). 


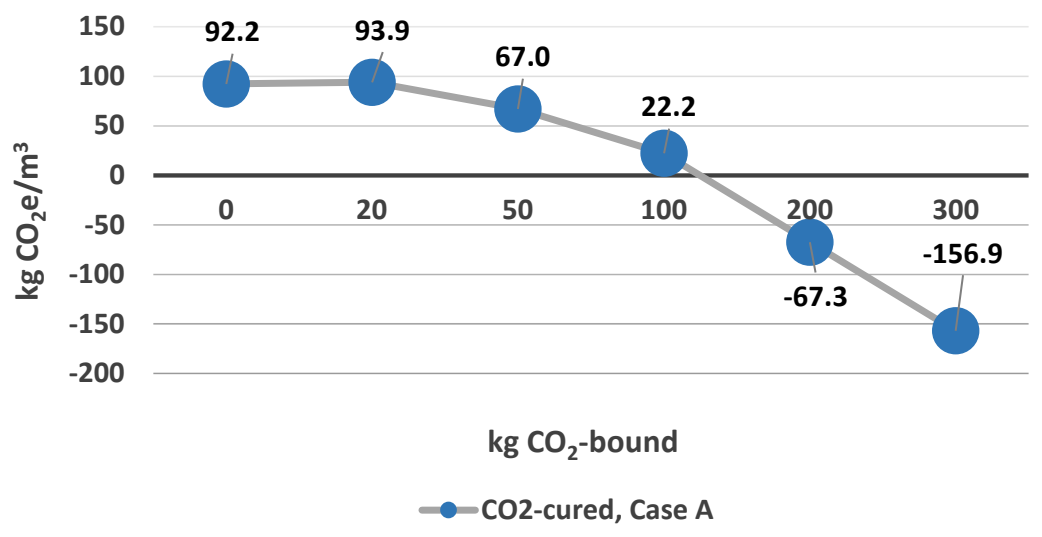

Figure 10 Sensitivity of carbon footprint to $\mathrm{CO}_{2}$ uptake in the material, Case $A$ (assessment is made for the life cycle stages A1-3).

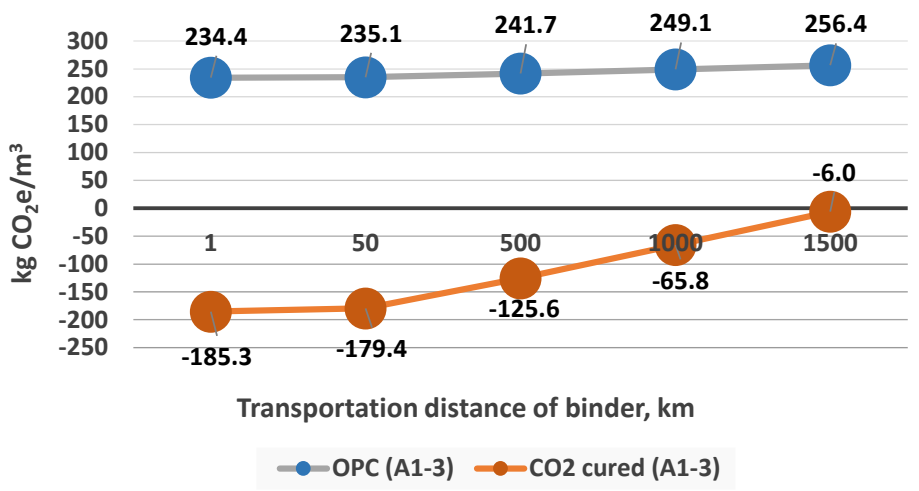

Figure 11 Sensitivity of carbon footprint to transport distance of binder material: $1 \mathrm{~km} \mathrm{...}$ $1500 \mathrm{~km}$. OPC is the concrete $\mathrm{C} 16 / 20$ and $\mathrm{CO}_{2}$-cured concrete represents Case $\mathrm{A}$.

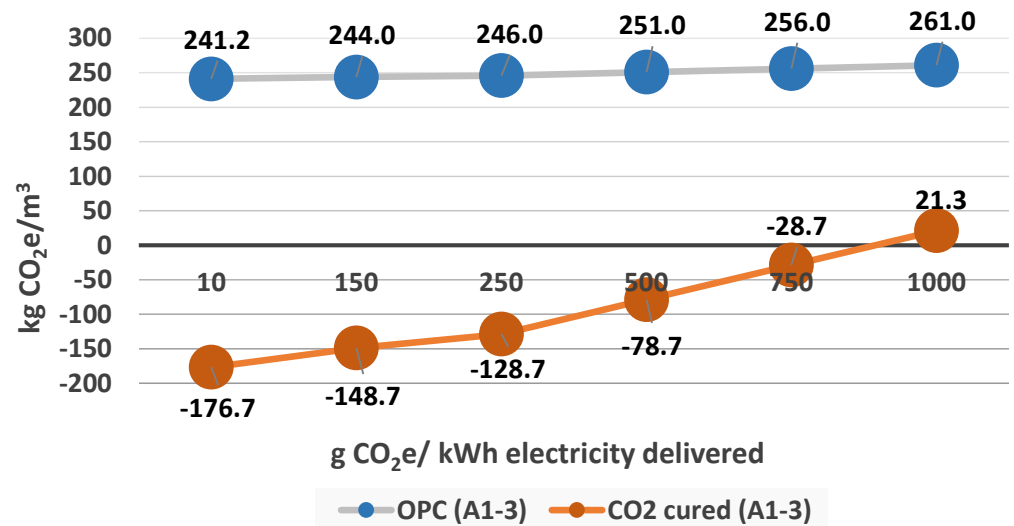

Figure 12 Sensitivity of carbon footprint to emission intensity of electricity (10 g $\mathrm{CO}_{2} / \mathrm{kWh}$ : wind-based electricity production, $109 \mathrm{~g} \mathrm{CO}_{2} / \mathrm{kWh}$ : average Finnish electricity, $1000 \mathrm{~g} \mathrm{CO}_{2} / \mathrm{kWh}$ : oil-shale-based electricity production). Note: OPC is the concrete $\mathrm{C} 16 / 20$ and $\mathrm{CO}_{2}$-cured concrete represents Case $\mathrm{A}$. 


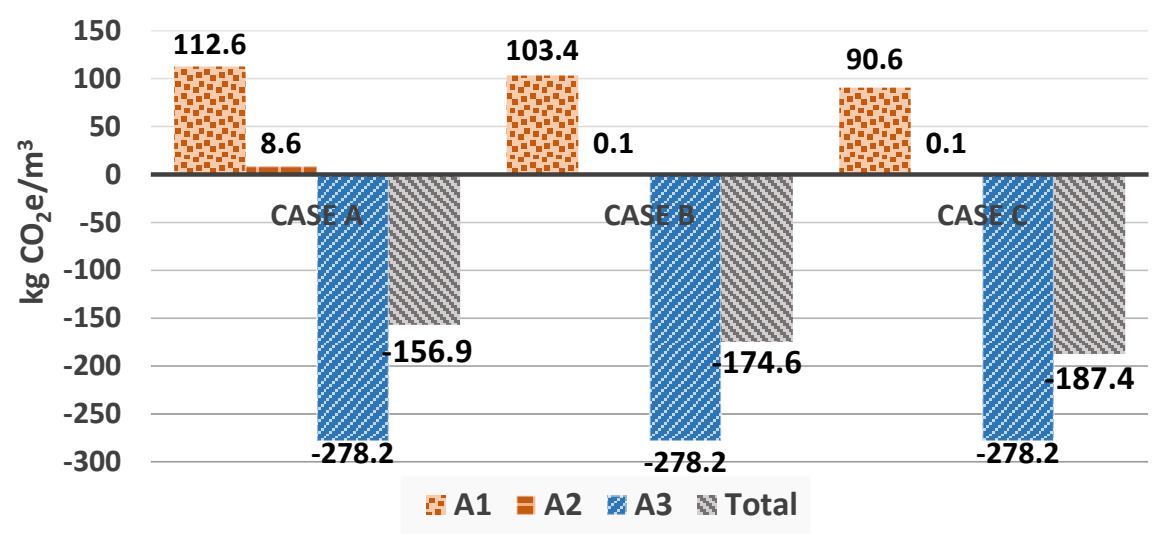

Figure 13 Sensitivity of carbon footprint to $\mathrm{CO}_{2}$ footprint of the $\mathrm{CO}_{2}$ source (Case A: $\mathrm{CO}_{2}$ source: pure $\mathrm{CO}_{2}$ from the Linde process; Case $\mathrm{B}: \mathrm{CO}_{2}$ source: compressed flue gas from Nordkalk/Raahe; and Case $\mathrm{C}$ : $\mathrm{CO}_{2}$ source: flue gas obtained from Nordkalk/Raahe).

The sensitivity assessment for the amount of bound $\mathrm{CO}_{2}$ shows that $\mathrm{CO}_{2}$ curing could outweigh carbon footprint emissions from the blast furnace slag concrete production stage (A1-3) when more than $100 \mathrm{~kg}$ of $\mathrm{CO}_{2}$ was bound to the concrete.

The transportation distance of cement exerts a much lower impact on the carbon footprint of concrete compared to that of blast furnace slag because of the lower binder content (13 wt.\% cement vs. $83 \mathrm{wt} . \%$ slags). It can also be attributed to the relatively strong influence of the raw materials compared to that of the blast furnace slag. Even so, the $\mathrm{CO}_{2}$ curing case could achieve a negative carbon footprint $\left(-6 \mathrm{~kg} \mathrm{CO}_{2} / \mathrm{m}^{3}\right)$ with a transportation distance as high as $1500 \mathrm{~km}$.

Figure 12 presents the sensitivity of the carbon footprints vs. the emission intensity of the electricity used. Conventional concrete production requires electricity $\left(20 \mathrm{kWh} / \mathrm{m}^{3}\right)$, But more energy is needed for $\mathrm{CO}_{2}$ curing $\left(200 \mathrm{kWh} / \mathrm{m}^{3}\right)$. The energy may be in the form of heat or electricity. While the specific process is not fully determined, we assume the full energy needed should be in the form of electricity. The difference in energy use is also seen in the carbon footprint pattern for life cycle stages A1-3. The carbon footprint result for OPC, between using wind power or coal-fired power, is not as critical for the process of concrete production as the $\mathrm{CO}_{2}$-cured concrete production process. The consequent differences are $(261-241=) 20 \mathrm{~kg} \mathrm{CO} 2 / \mathrm{m}^{3}$ and $(21-(-177)=) 198 \mathrm{~kg} \mathrm{CO} 2 \mathrm{e} / \mathrm{m}^{3}$.

The sensitivity analysis for the $\mathrm{CO}_{2}$ source shows that a negative carbon footprint of - $157 \mathrm{~kg}$ $\mathrm{CO}_{2} \mathrm{e} / \mathrm{m}^{3}$ is achieved when $300 \mathrm{~kg} \mathrm{CO}$ is bound to concrete during the production process in Case A. An even higher benefit of $-187 \mathrm{~kg} \mathrm{CO} 2 \mathrm{e} / \mathrm{m}^{3}$ could be achieved when the source for $\mathrm{CO}_{2}$ curing is flue gas (Case $\mathrm{C}$ ).

\subsection{Role of $\mathrm{CO}_{2}$-Cured Alternative Binder Concrete}

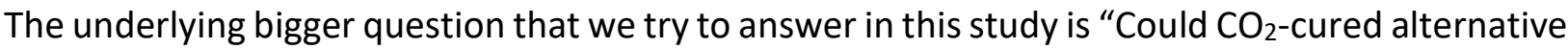
binder concrete help in significantly reducing the $\mathrm{CO}_{2}$ emissions?" Figure 7 shows that in Finland, there seem to be enough potential secondary material streams (about $27 \mathrm{Mt} / \mathrm{a}$ ) that could be utilized to substitute the entire concrete production of Finland (11.2 Mt/a) with alternative binders if logistics can be efficiently arranged. In the case of Finland, long transportation distances may hinder the development of some otherwise potential uses. The current annual concrete production 
in Finland amounts to approximately $11 \mathrm{Mt} / \mathrm{a}$ or $4.97 \mathrm{Mm}^{3}$ (assuming an average density of 2250 $\mathrm{kg} / \mathrm{m}^{3}$ ). The emissions (including used steel reinforcements $0.113 \mathrm{Mt} \mathrm{CO}_{2}$ ) are estimated to be approximately $1.1 \mathrm{Mt}$ of $\mathrm{CO}_{2}$. The carbon footprint of concrete (excluding reinforcements) could be lowered from about $200 \mathrm{~kg} \mathrm{CO} / \mathrm{m}^{3}\left(179 \mathrm{~kg} \mathrm{CO} 2 / \mathrm{m}^{3} \ldots 244 \mathrm{~kg} \mathrm{CO} / \mathrm{m}^{3}\right)$ to $-170 \mathrm{~kg} \mathrm{CO} / \mathrm{m}^{3}(-157 \mathrm{~kg}$ $\mathrm{CO}_{2} / \mathrm{m}^{3} \ldots-187 \mathrm{~kg} \mathrm{CO} / \mathrm{m}^{3}$ ) (saving: $370 \mathrm{~kg} \mathrm{CO} / \mathrm{m}^{3}$ of concrete produced).

Two substitution scenarios are considered: (1) substituting all concrete production and (2) substituting only precast concrete. Note that the emissions from steel reinforcements are not affected in either scenario. In the first scenario, if all the concrete produced in Finland were substituted with the presented $\mathrm{CO}_{2}$-cured alternative binder concrete, it would lead to an annual net reduction that can be estimated from Equation 12 as follows:

$$
\begin{gathered}
\qquad \mathrm{Net} \mathrm{CO}_{2} \text { reduction }\left[\frac{\mathrm{kg}}{\mathrm{a}}\right] \\
=\text { Concrete production of Finland }\left[\frac{\mathrm{m}^{3}}{\mathrm{a}}\right] * \text { Specific emission savings }\left[\frac{\mathrm{kg}}{\mathrm{m}^{3}}\right] \\
=4970000 \mathrm{~m} 3 / \mathrm{a}^{*} 370 \mathrm{~kg} \mathrm{CO} / \mathrm{m}^{3}=1838900000 \mathrm{~kg} \mathrm{CO} / \mathrm{a} \approx 1.84 \mathrm{Mt} \mathrm{CO}_{2} / \mathrm{a},
\end{gathered}
$$

This corresponds to a $167 \%$ reduction in the emissions of the entire concrete industry. In comparison, CCS and switching to bioenergy in the cement industry was estimated to have a $\mathrm{CO}_{2}$ emission reduction potential of approximately $1.1 \mathrm{Mt} \mathrm{CO}_{2} / \mathrm{a}$ [37] (p. 31).

In the second scenario, if only precast concrete production was substituted with the presented $\mathrm{CO}_{2}$-cured alternative binder concrete, the net $\mathrm{CO}_{2}$ reduction, based on production volume shares of ready-mix and precast concrete (7.4 Mt/a and 3.8 Mt/a, respectively), would be approximately $(3.8 \mathrm{Mt} / \mathrm{a} /(3.8 \mathrm{Mt} / \mathrm{a}+7.4 \mathrm{Mt} / \mathrm{a})) * 1.84 \mathrm{Mt} \mathrm{CO} / \mathrm{a}=0.62 \mathrm{Mt} \mathrm{CO} / \mathrm{a}$.

The net emissions are calculated for the first scenario according to Equation 13 as follows:

$$
\begin{aligned}
& \text { Net emissions of } \mathrm{CO}_{2}-\text { cured concrete }\left[\mathrm{Mt} \frac{\mathrm{CO}_{2}}{a}\right] \\
& =\text { Current } \mathrm{CO}_{2} \text { emissions of concrete production }\left[\mathrm{Mt} \frac{\mathrm{CO}_{2}}{\mathrm{a}}\right] \\
& -\mathrm{Net} \mathrm{CO}_{2} \text { reduction }\left[\mathrm{Mt} \frac{\mathrm{CO}_{2}}{\mathrm{a}}\right] \\
& =1.1 \mathrm{MtCO} / \mathrm{a}-1.84 \mathrm{MtCO} / \mathrm{a}=-0.74 \mathrm{MtCO} / \mathrm{a} \text {. }
\end{aligned}
$$

This corresponds to the concrete industry shifting from currently emitting $1.87 \%$ of the $\mathrm{CO}_{2}$ emissions in Finland to removinge $1.26 \%$ of the emissions in Finland, i.e., a saving of $3.13 \%$ of the entire $\mathrm{CO}_{2}$ emissions of the country.

Similarly, in the second scenario, if only precast concrete was substituted, the net emission from concrete would be $1.1 \mathrm{Mt} \mathrm{CO} / \mathrm{a}-0.62 \mathrm{Mt} \mathrm{CO}_{2} / \mathrm{a}=0.48 \mathrm{Mt} \mathrm{CO}_{2} / \mathrm{a}$, which would still be a significant reduction in emission. Relative to the total $\mathrm{CO}_{2}$ emission in Finland, this correlates to a reduction from $1.87 \%$ to $0.82 \%$.

These considerations bring us to a conclusion that, in the case of the concrete industry in Finland, $\mathrm{CO}_{2}$-cured alternative binder concrete has the potential to become a breakthrough technology that can be used to reduce the emission from the industry. This can significantly contribute to the emission reductions in Finland. These quantitative results cannot be generalized for other countries as such, but it clearly shows that, at least in some countries where pulp and paper industries, mining 
or steel industries, or a significant number of combustion-based power plants are present, the potential of $\mathrm{CO}_{2}$-cured alternative binder concrete is worth studying.

$\mathrm{CO}_{2}$-cured alternative binder concrete can address the most difficult process emissions in the field of cement production. Moreover, valuable carbon-negative products can be obtained. The transformation of waste to raw materials adds value to the economy. This allows the development of new business opportunities, jobs, and sustainable growth. The immediate economic drivers include the avoided landfilling cost of wastes and savings from raw materials, which create a margin for the transportation costs of secondary raw materials. To optimize logistics and enable widespread use of secondary raw materials, broad collaboration efforts are needed. Moreover, the economic feasibility of these concepts will depend on the efficiency of both logistics and processing. For instance, the selection of the location of the production facility affects both the quality and volume of available raw materials, both solids and $\mathrm{CO}_{2}$. Good locations would benefit from nearby highlyconcentrated $\mathrm{CO}_{2}$ sources (e.g., cement kilns and biogas plants), high-volume, good-quality secondary raw material sources (power plants, mines, and steel mills), good transport connections (railroad and shipping lines), and proximity to product delivery sites (cities and large developing industrial sites).

However, the technology has been proven in pilots only with blast furnace slags, cement kiln dust and coal fly ashes for other materials and more demanding products, such as bridges, the technology readiness level is still low. There is great difficulty in using various types of raw materials in an industry producing vast amounts of bulk products that should be safe and reliable. To speed up the implementation of this high-potential technology, more experience with new materials is needed. Rapid development would greatly benefit from specific product demonstrations (e.g., blocks, block wall elements, and hollow-core slabs), process development, local secondary raw material explorations, heavy investment subsidies, a strict $\mathrm{CO}_{2}$ budget for buildings, a standard for alternative binder concretes, and the inclusion of mineralization in the EU ETS legislation or similar $\mathrm{CO}_{2}$ emissions trading schemes outside Europe.

Only 15 years remain to reach the pledged goal of carbon-neutral Finland (by 2035) and only 15 more for the targeted carbon-neutral European Union (by 2050) [95]. This is a short period of time to implement new technology, and the sooner strategic choices are made by the governments and major companies, the better it would be. In the meanwhile, immediate actions can help in reducing the emissions. Improved construction design, longer lifespans of concrete structures, improved recycling, switching to biofuels, transporting with biogas trucks, buying renewable electricity or installing own production, energy efficiency, and use of blending cement can help in reducing emission. Energy transition measures can especially be applied throughout the concrete production chain.

\section{Conclusions}

We have assessed the $\mathrm{CO}_{2}$ emission reduction potential of $\mathrm{CO}_{2}$-cured alternative binder concrete with respect to the amount of available alternative binders suitable for $\mathrm{CO}_{2}$ curing. The respective amounts of $\mathrm{CO}_{2}$ bound (for the case of Finland) were also studied. In addition, we used a life-cycle assessment tool to compare the carbon footprint of a conventionally manufactured concrete block and a modeled $\mathrm{CO}_{2}$-cured blast furnace slag block.

Our primary observations are as follows: 
- Nationwide in Finland, there are enough potential secondary raw materials for $\mathrm{CO}_{2}$ curing (about $27 \mathrm{Mt} / \mathrm{a}$ ) to replace the current cement production (1.4 Mt/a) or even the entire concrete production (about $11.2 \mathrm{Mt} / \mathrm{a}$ ).

- The $\mathrm{CO}_{2}$ uptake potential of these streams was estimated to be $1.9 \mathrm{Mt} \mathrm{CO}_{2} / \mathrm{a}$ (vs. emissions of cement production in Finland $0.84 \mathrm{Mt}$ ) if all available material streams were fully carbonated.

- The most potential material streams were mine tailings and recycled concrete (large volumes, but with low reactivity), steelmaking and blast furnace slags (large volumes, piloted technology, but mostly utilized already), and biomass ashes (exhibiting good $\mathrm{CO}_{2}$ uptake potential and high reactivity; sulfur content may cause risks).

- $\mathrm{CO}_{2}$ curing is most feasible for use in precast concrete products, such as concrete blocks, pavement stones, and hollow-core slabs, where products can be sealed in an atmosphere of $\mathrm{CO}_{2}$. The size of the surface area exposed to $\mathrm{CO}_{2}$ is large compared to the product volume. $\mathrm{CO}_{2}$ uptake control is needed to retain safe $\mathrm{pH}$ levels for steel reinforcements.

- The carbon footprint calculation for LCA stages A1-3, assuming a $\mathrm{CO}_{2}$ uptake of $300 \mathrm{~kg} \mathrm{CO} / \mathrm{m}^{3}$ concrete, resulted in a negative carbon footprint of $-157 \mathrm{~kg} \mathrm{CO} \mathrm{CO}_{2} \mathrm{e} \mathrm{m}^{3}$ (with purified $\mathrm{CO}_{2}$ ) and $-187 \mathrm{~kg} \mathrm{CO} 2 \mathrm{e} / \mathrm{m}^{3}$ (with flue gas) (vs. conventional concrete $243 \mathrm{~kg} \mathrm{CO} \mathrm{C}_{2} \mathrm{e} / \mathrm{m}^{3}$ ). The maximal emission savings represents the difference in carbon footprints $\left(430 \mathrm{~kg} \mathrm{CO}_{2} \mathrm{e} / \mathrm{m}^{3}\right)$ when substituting conventional concrete with $\mathrm{CO}_{2}$-cured blast furnace slag concrete (using flue gas as such).

- If all the concrete produced in Finland could be replaced with $\mathrm{CO}_{2}$-cured alternative binder concretes, the emission from concrete production would change from $1.9 \%$ of the emissions in Finland to $-1.3 \%$ (a net reduction by $3.1 \%$ ). If only precast concrete is substituted, the emissions from the concrete industry would be lowered: a remaining emission of $0.8 \%$ (of the national $\mathrm{CO}_{2}$ emission; a net reduction by $1.1 \%$ ) would be observed.

$\mathrm{CO}_{2}$-cured alternative binder concrete can address even the most difficult process emissions of cement production and result in the generation of valuable carbon-negative products. The present study has shown that it could advance sustainability in many ways. It can enable better use of secondary raw materials and significantly reduce $\mathrm{CO}_{2}$ emissions. The method can also provide new business opportunities. The barriers of low technology readiness levels for many locally interesting materials and unknown long-term properties could be overcome by employing well-tested local raw material testing methods and financially supported demonstrations in specific products. The changes in regulation and standardization processes and a more specific and well-communicated $\mathrm{CO}_{2}$ emissions reduction strategy promoted by the governments (especially with regards to CCS) can help in the process. The quantitative results obtained by studying the cases in Finland are not representative of other countries because the construction methods, the readiness of the industry to change, secondary raw material streams, political pressure, and legislation are likely to vary. Nevertheless, the study shows that at least in countries where pulp and paper industries, mining or steel industries, or a significant number of combustion-based power plants are present, the potential of $\mathrm{CO}_{2}$-cured alternative binder concrete is worth studying. Such studies can help in drastically lowering the emissions of the construction industry. 


\section{Acknowledgements}

This research is funded by the Finnish government grant to VTT.

\section{Author Contributions}

Mäkikouri, Sampo: Conceptualization, Investigation, Writing - Original Draft, Project administration. Korpijärvi, Kirsi: Methodology, Investigation, Validation, Data Curation, Writing Original Draft. Vares, Sirje: Methodology, Investigation, Formal analysis, Writing - Original Draft. Papakonstantinou, Nikolaos: Software, Visualization, Writing - Review \& Editing.

\section{Competing Interests}

The authors have declared that no competing interests exist.

\section{References}

1. Rogelj J, Shindell D, Jiang K, Fifita S, Forster P, Ginzburg V, et al. Mitigation pathways compatible with $1.5^{\circ} \mathrm{C}$ in the context of sustainable development [Internet]. Genève: Intergovernmental Panel on Climate Change; 2018. Available from: https://www.ipcc.ch/site/assets/uploads/sites/2/2019/02/SR15 Chapter2 Low Res.pdf.

2. Government Programme. Programme of Prime Minister Antti Rinne's government 6 June 2019 inclusive and competent Finland-A socially, economically and ecologically sustainable society [Internet]. Finland: Finnish Government; 2019. Available from: http://urn.fi/URN:ISBN:978-952287-760-4.

3. Lehne J, Preston F. Making concrete change: Innovation in low-carbon cement and concrete. London: Chatham House Report; 2018.

4. Becken S, Miller G. Aviation Emissions-Global Sustainable Tourism Dashboard [Internet]. Brisbane, QLD: Griffith University; 2018 [cited 2019 July 31st]. Available from: https://www.tourismdashboard.org/explore-the-data/carbon-emissions/.

5. Bosoaga A, Masek O, Oakey JE. $\mathrm{CO}_{2}$ capture technologies for cement industry. Energy Procedia. 2009; 1: 133-140.

6. Finnsementti. Ympäristöraportti 2018 [Internet]. Espoo: Finnsementti; 2018. Available from: https://finnsementti.fi/wpcontent/uploads/2018/09/Finnsementti ymparistoraportti 2018.pdf.

7. Müller N, Harnisch J. A blueprint for a climate friendly cement industry [Internet]. Switzerland: WWF International; 2008. Available from: https://wwfint.awsassets.panda.org/downloads/englishsummary Ir pdf.pdf.

8. Finnsementti. Ympäristöraportti 2020 [Internet]. Espoo: Finnsementti; 2020. Available from: https://finnsementti.fi/wp-content/uploads/Finnsementti ymparistoraportti 2020.pdf.

9. Finnish Environment Institute SYKE. Emissions database for construction [Internet]. Helsinki: Finnish Environment Institute SYKE; 2021 [cited 2021 March 11th]. Available from: https://co2data.fi/.

10. ECOCEM. Environmental Product Declaration for Ecocem Ggbs Cement [Internet]. Nieuwegein: Milieu Relevante Product Informatie; 2013. Available from: https://www.igbc.ie/wpcontent/uploads/2017/09/MRPI-certificate-EPD-Ecocem-GGBS.pdf. 
11. Teknologian tutkimuskeskus VTT Oy. LIPASTO Unit emissions-Maansiirtoauto ilman perävaunua [Internet]. Espoo: Teknologian tutkimuskeskus VTT Oy; 2018 [cited 2021 March 11th]. Available from: http://lipasto.vtt.fi/yksikkopaastot/tavaraliikenne/tieliikenne/kamaanstie.htm.

12. Ville V, Suomen virallinen tilasto. Kasvihuonekaasut (Greenhouse gases). Suomen kasvihuonekaasupäästöt 2016 (Greenhouse gas emissions of Finland 2016). Helsinki: Statistics Finland; 2017.

13. Betoniteollisuus ry. RT/Betoniteollisuus-tilastotietoja (Finnish Concrete Industry AssociationStatistics) [Internet]. Helsinki: Betoniteollisuus ry; 2019. Available from: https://betoni.com/wpcontent/uploads/2019/09/Betoniteollisuuden-yhteenvetotaulukko-2018.pdf.

14. International Stainless Steel Forum. Stainless steel and $\mathrm{CO}_{2}$ : Facts and scientific observations [Internet]. Brussels: International Stainless Steel Forum; 2019. Available from: https://www.worldstainless.org/Files/issf/non-imagefiles/PDF/ISSF Stainless Steel and CO2.pdf.

15. Ahmad S. Reinforcement corrosion in concrete structures, its monitoring and service life prediction-a review. Cem Concr Compos. 2003; 25: 459-471.

16. Lagerblad B. Carbon dioxide uptake during concrete life cycle: State of the art. Stockholm: Swedish Cement and Concrete Research Institute; 2005.

17. Yang $\mathrm{KH}$, Seo EA, Tae SH. Carbonation and $\mathrm{CO}_{2}$ uptake of concrete. Environ Impact Assess Rev. 2014; 46: 43-52.

18. Xi F, Davis SJ, Ciais P, Crawford-Brown D, Guan D, Pade C, et al. Substantial global carbon uptake by cement carbonation. Nat Geosci. 2016; 9: 880-883.

19. García-Segura T, Yepes V, Alcalá J. Life cycle greenhouse gas emissions of blended cement concrete including carbonation and durability. Int J Life Cycle Assess. 2014; 19: 3-12.

20. Possan E, Felix EF, Thomaz WA. $\mathrm{CO}_{2}$ uptake by carbonation of concrete during life cycle of building structures. J Build Pathol Rehabil. 2016; 1: 1-9.

21. Engelsen CJ, Mehus J, Pade C, Sæther DH. Carbon dioxide uptake in demolished and crushed concrete. $\mathrm{CO}_{2}$ uptake during the concrete life cycle. Norway: Nordic Innovation; 2005. Available from:

https://sintef.brage.unit.no/sintefxmlui/bitstream/handle/11250/2418901/Prosjektrapport395.pdf?sequence=1.

22. Comite Europeen de Normalisation. Sustainability of construction works-environmental product declarations-product category rules for concrete and concrete elements. Brussels: Comite Europeen de Normalisation; 2017; EN 16757: 2017.

23. Possan E, Thomaz WA, Aleandri GA, Felix EF, dos Santos AC. $\mathrm{CO}_{2}$ uptake potential due to concrete carbonation: A case study. Case Stud Constr Mater. 2017; 6: 147-161.

24. Siriwardena DP, Peethamparan $\mathrm{S}$. Quantification of $\mathrm{CO}_{2}$ sequestration capacity and carbonation rate of alkaline industrial byproducts. Constr Build Mater. 2015; 91: 216-224.

25. Dindi A, Quang DV, Vega LF, Nashef E, Abu-Zahra MR. Applications of fly ash for $\mathrm{CO}_{2}$ capture, utilization, and storage. J CO $\mathrm{CO}_{2}$ Util. 2019; 29: 82-102.

26. Vassilev SV, Vassileva CG. Extra $\mathrm{CO}_{2}$ capture and storage by carbonation of biomass ashes. Energy Convers. Manag. 2020; 204: 112331.

27. Sanna A, Dri M, Hall MR, Maroto-Valer M. Waste materials for carbon capture and storage by mineralisation (CCSM)-A UK perspective. Appl Energy. 2012; 99: 545-554.

28. Ohenoja K, Rissanen J, Kinnunen P, Illikainen M. Direct carbonation of peat-wood fly ash for carbon capture and utilization in construction application. J CO2 Util. 2020; 40: 101203. 
29. Huijgen WJ, Comans RN, Witkamp GJ. Cost evaluation of $\mathrm{CO}_{2}$ sequestration by aqueous mineral carbonation. Energy Convers Manag. 2007; 48: 1923-1935.

30. Renforth P. The negative emission potential of alkaline materials. Nat Commun. 2019; 10: 1401.

31. CEMBUREAU. The Role of Cement in the 2050 Low Carbon Economy [Internet]. Brussels: CEMBUREAU; 2013. Available from: https://lowcarboneconomy.cembureau.eu/wpcontent/uploads/2018/09/cembureau-executive-summary.pdf.

32. Fischedick M, Roy J, Abdel-Aziz A, Acquaye A, Allwood J, Ceron JP. Industry. In: Climate change 2014: Mitigation of climate change. Contribution of working group III to the fifth assessment report of the intergovernmental panel on climate change. Cambridge: Cambridge University Press; 2014. pp.739-810.

33. Suomen Standardisoimisliitto SFS ry. Cement. Part 1: Composition, specifications and conformity criteria for common cements. Helsinki: Finnish Standards Association SFS; 2012; SFSEN 197-1.

34. Finnsementti Oy. Technical data sheet [Internet]. Espoo: Finnsementti; 2019 [cited 2020 April 8th]. Available from: https://finnsementti.fi/wpcontent/uploads/Rapidsementti Parainen eng.pdf.

35. Vares S, Penttala V. Environmental impact of increased use of mineral additive binders in concrete. Proceedings of the Int'l Conference on Sustainability in the Cement and Concrete Industry; 2007 Seeptember 16th; Lillehammer, Norway. Finland: VTT.

36. Nordbäck N. Report on status and capacities of geological $\mathrm{CO}_{2}$ storage in the surrounding regions to Finland. Helsinki: CLEEN LTD; 2014; Research Report nr D534.

37. Rørvik K-L, Ringrose P. How Norway is building a full-scale CCS value chain [Internet]. Norway: CCS Norway; 2018. Available from: http://www.rite.or.jp/news/events/pdf/5-Kari-LiseCCSWS20180123.pdf.

38. Norcem. Heidelberg Cement group, carbon capture-a part of our zero vision [Internet]. Oslo: Norcem; [cited 2019 August 14th]. Available from: https://www.norcem.no/en/carbon capture.

39. Sandbag. Tracking the European Union Emissions Trading System carbon market price day-byday. [cited 2021 May 7th]. Available from: https://sandbag.be/index.php/carbon-price-viewer/.

40. Gardarsdottir SO, De Lena E, Romano M, Roussanaly S, Voldsund M, Pérez-Calvo JF, et al. Comparison of technologies for $\mathrm{CO}_{2}$ capture from cement production-Part 2: Cost analysis. Energies. 2019; 12: 542.

41. Granskog A, Gulli C, Melgin T, Naucler T, Speelman E, Toivola L, et al. Cost-efficient emission reduction pathway to 2030 for Finland-opportunities in electrification and beyond [Internet]. Helsink: Sitra Studies; 2018. Available from: https://media.sitra.fi/2018/11/30102722/costefficient-emission-reduction-pathway-to-2030-for-finland.pdf.

42. Raivio T, Laine A, Klimscheffskij M, Heino A, Lehtomäki J. Vähähiilinen rakennusteollisuus 2035Osa 4. Rakennusteollisuuden ja rakennetun ympäristön vähähiilisyyden tiekartta 2020-20352050 [Internet]. Turku: Gaia Consulting Oy; 2020. Available from: https://www.rakennusteollisuus.fi/globalassets/ymparisto-jaenergia/vahahiilisyys uudet/rt 4.-raportti vahahiilisyyden-tiekartta lopullinenversio clean.pdf.

43. The Building Information Foundation RTS. Parma Consolis Environmental product declaration. Hollow core slab. 2019; RTS EPD 28_19.

44. Jang JG, Kim GM, Kim HJ, Lee HK. Review on recent advances in $\mathrm{CO}_{2}$ utilization and sequestration 
technologies in cement-based materials. Constr Build Mater. 2016; 127: 762-773.

45. Erlund R, Koivisto $E$, Fagerholm M, Zevenhoven R. Extraction of magnesium from four Finnish magnesium silicate rocks for $\mathrm{CO}_{2}$ mineralisation-part 2: Aqueous solution extraction. Hydrometallurgy. 2016; 166: 229-236.

46. Teir S, Hetland J, Lindeberg E, Torvanger A, Buhr K, Koljonen T, et al. Potential for carbon capture and storage (CCS) in the Nordic region. Espoo: VTT research notes. 2010. pp.2556.

47. European Commission. Directive 2009/31/EC of the European Parliament and of the Council of 23 April 2009 on the geological storage of carbon dioxide and amending Council Directive 85/337/EEC, European Parliament and Council Directives 2000/60/EC, 2001/80/EC, 2004/35/EC, 2006 [Internet]. Brussel: European Commission; 2018. Available from: http://data.europa.eu/eli/dir/2009/31/2018-12-24.

48. European Court of Justice (First Chamber), Judgment of the Court (First Chamber) of 19 January 2017. Schaefer Kalk GmbH \& Co. KG v Bundesrepublik Deutschland. Request for a preliminary ruling from the Verwaltungsgericht Berlin. Reference for a preliminary ruling-EnvironmentScheme for greenhou, 2017. Available from: https://eur-lex.europa.eu/legalcontent/EN/TXT/?uri=CELEX\%3A62015CJ0460.

49. Favier A, Wolf De C, Scrivener K, Habert G. A sustainable future for the european cement and concrete industry technology assessment for full decarbonisation of the industry by 2050 [Internet]. Lausanne: École Polytechnique Fédérale de Lausanne; 2018. Available from: https://europeanclimate.org/wpcontent/uploads/2018/10/AB SP Decarbonisation report.pdf.

50. Solidia Technologies. Solidia ${ }^{\circledR}$-sustainable cement manufacturing and concrete curing technologies [Internet]. Piscataway: Solidia Technologies; 2020 [cited 2020 January 22nd]. Available from: https://www.solidiatech.com/solutions.html.

51. Wessel A, Cialdella R, McPherson J. CarbonCure Technologies [Internet]. Dartmouth: Carbon Cure; 2020 [cited 2020 January 22nd]. Available from: https://www.carboncure.com/.

52. Orbix. Carbonation technology [Internet]. Genk: Orbix; 2018 [cited 2020 January 22th]. Available from: https://www.orbix.be/en/carbonation-technology.

53. CarbiCrete. Cement-free, carbon-negative concrete [Internet]. Lachine: Carbicrete; 2018 [cited 2020 January 22th]. Available from: http://carbicrete.com/.

54. Yoshioka K, Obata D, Nanjo H, Yokozeki K, Torichigai T, Morioka M, et al. New ecological concrete that reduces $\mathrm{CO}_{2}$ emissions below zero level new method for $\mathrm{CO}_{2}$ capture and storage . Energy Procedia. 2013; 37: 6018-6025.

55. Ravikumar D, Zhang D, Keoleian G, Miller S, Sick V, Li V. Carbon dioxide utilization in concrete curing or mixing might not produce a net climate benefit. Nat Commun. 2021; 12: 1-13.

56. Siauciunas R, Hilbig H, Prichockiene E, Smigelskyte A, Takulinskas Z. Accelerated carbonation of $\mathrm{C}_{2} \mathrm{SH}$ based dense concrete. Ceram Int. 2020; 46: 29436-29442.

57. Lyubomirskiy N, Bakhtin A, Fic S, Szafraniec M, Bakhtina T. Intensive ways of producing carbonate curing building materials based on lime secondary raw materials. Materials. 2020; 13: 2304.

58. Sanjuán MÁ, Estévez E, Argiz C. Carbon dioxide absorption by blast-furnace slag mortars in function of the curing intensity. Energies. 2019; 12: 2346.

59. Pu L, Unluer C. Durability of carbonated $\mathrm{MgO}$ concrete containing fly ash and ground granulated blast-furnace slag. Constr Build Mater. 2018; 192: 403-415. 
60. Kim S, Park C. Durability and mechanical characteristics of blast-furnace slag based activated carbon-capturing concrete with respect to cement content. Appl Sci. 2020; 10: 2083.

61. Carbicrete. Technology [Internet]. Lachine: Carbicrete; 2018 [cited 2019 October 8th]. Available from: http://carbicrete.com/technology/.

62. Ministry of Economic Affairs and Employment of Finland. Minister Tiilikainen: Finland to ban coal in 2029-incentives package for faster phase-out [Internet]. Finland: Ministry of Economic Affairs and Employment of Finland; 2018 [cited 2019 October 8th]. Available from: https://tem.fi/en/article/-/asset publisher/ministeri-tiilikainen-kivihiilen-kielto-2029kannustepaketti-nopeille-luopujille.

63. Steinour HH. Some effects of carbon dioxide on mortars and concrete-discussion. J Am Concr Inst. 1959; 30: 905-907.

64. Huntzinger DN, Gierke JS, Kawatra SK, Eisele TC, Sutter LL. Carbon dioxide sequestration in cement kiln dust through mineral carbonation. Environ Sci Technol. 2009; 43: 1986-1992.

65. European Committee for Standarization. Greenhouse gases. Carbon footprint of products Requirements and guidelines for quantification. Genève: International Organization for Standardization; 2018; ISO 14607:2018.

66. European Committee for Standarization. Sustainability of construction works. Environmental product declarations. Core rules for the product category of construction products. Newark: iTeh Inc; 2019; EN 15804:2012+A2:2019.

67. Finnsementti Oy. Concrete recipe calculator (Betonireseptilaskuri) [Internet]. Espoo: Finnsementti Oy; [cited 2020 March 26th]. Available from: https://finnsementti.fi/betonilaskuri/.

68. Finnsementti Oy. Environmental data sheet. Lappeenranta: Production site; 2016.

69. VTT. VTT: N vuosi 2020: Menestyksekäs vuosi globaalisti haastavasta ajasta huolimatta [Internet]. Espoo: VTT; [cited 2020 February 17th]. Available from: https://www.vtt.fi/sites/ilmari/ilmariarviointipalvelu.

70. Linde-engineering. Carbon capture, storage and utilization. Linde \& BASF team up to innovate carbon capture [Internet]. Tulsa: Linde-engineering; 2020 [cited 2020 February 19th]. Available from: $\quad$ https://www.linde-engineering.com/en/images/Carbon-capture-storage-andutilisation tcm19-462558.pdf.

71. VTT. SULCA-Sustainability tool for Ecodesign, Footprints \& LCA [Internet]. Espoo: SimulationStore; 2014 [cited 2020 March 26th]. Available from: https://www.simulationstore.com/sulca.

72. Finnish Energy. Energy Year 2020. Electricity. Helsinki: Finnish Energy; 2020. Available from: https://energia.fi/files/4381/Energy Year 2019 - Electricity.pdf.

73. Mechelen DV, Quaghebeur M, Nielsen P. Method for producing a bonded article comprising a press-moulded, carbonated granular material. Genève: World Intellectual Property Organization; WO2013060870A1; 2013.

74. H. Lachmund, P. Van Mierloo, Project overview „DICO2STONE“, Dillinger Orbix, in: Eur. Ind. Stakehold. Work. 22.03.2018, 2018.

75. Teir D, Pikkarainen T, Kujanpää L, Tsupari E, Kärki J, Arasto A, et al. Hiilidioksidin talteenotto ja varastointi (CCS) [Internet]. Espoo: VTT; 2011. Available from: https://www.vttresearch.com/sites/default/files/pdf/workingpapers/2011/W161.pdf.

76. European Environment Agency. The European Pollutant Release and Transfer Register (E-PRTR), 
Member States reporting under Article 7 of Regulation (EC) No 166/2006 [Internet]. Copenhagen : European Environment Agency; 2019 [cited 2019 August 12th]. Available from: https://www.eea.europa.eu/data-and-maps/data/member-states-reporting-art-7-under-theeuropean-pollutant-release-and-transfer-register-e-prtr-regulation-21\#tab-data-visualisations.

77. Eriksson M, Hökfors B, Backman R. Oxyfuel combustion in rotary kiln lime production. Energy Sci Eng. 2014; 2: 204-215.

78. AGA. A member of the Linde Group. Industrial Gases [Internet]. Product brochure. 2020. Available from: https://www.lindegas.dk/en/images/AGA\%20CO2\%20Industrial\%20Quality\%20Datasheet\%20UK tcm571101346.pdf.

79. Espo J, Lesonen N, Pakarinen J. Kaivosten kokonaisnostosta valtaosa päätyy jätteeksi [Internet]. Helsinki: tilastokeskus; $2019 . \quad$ Available from: https://www.tilastokeskus.fi/tietotrendit/artikkelit/2019/kaivosten-kokonaisnostosta-valtaosapaatyy-jatteeksi/.

80. Solismaa S, Ismailov $A$, Karhu $M$, Sreenivasan $H$, Lehtonen $M$, Kinnunen $P$, et al. Valorization of Finnish mining tailings for use in the ceramics industry. Bull Geol Soc Finland. 2018; 90: 33-54.

81. Kauppila $\mathrm{P}$, Räsänen $\mathrm{ML}$, Myllyoja S. Best environmental practices in metal ore mining (Metallimalmikaivostoiminnan parhaat ympäristökäytännöt). Helsinki: Finnish Environment Institute; 2011.

82. Romão IS. Production of magnesium carbonates from serpentinites for $\mathrm{CO}_{2}$ mineral sequestration-optimisation towards industrial application. Coimbra: University of Coimbra; Turku: Åbo Akademi University; 2015. Available from: https://pdfs.semanticscholar.org/e1e0/2dc26792bd0b21859e2e0874ee5a976196f1.pdf.

83. Zevenhoven $\mathrm{R}$, Romão $\mathrm{I}$, Slotte $\mathrm{M}$. Mineralisation of $\mathrm{CO}_{2}$ using serpentinite rock-towards industrial application. Proceedings of the 2013 World Resources Forum Conference; 2013 October 6th-9th; Davos, Switzerland. Cheltenham: IEA GHG.

84. Breysse D. 3-Deterioration processes in reinforced concrete: An overview. Civ Struct Eng. 2010; 1: 28-56.

85. Ministry of the Environment-Finland. Government Decree on Recovery of Certain Wastes in Earth Construction 843/2017 [Internet]. Helsinki: The Government of Finland; 2017. Available from: https://www.finlex.fi/en/laki/kaannokset/2017/en20170843.pdf.

86. Mikko V. Technical properties of waste foudry sand and its use in earth construction [Internet]. Espoo: Aalto University; 2019. Available from: http://urn.fi/URN:NBN:fi:aalto-201910275955.

87. Vehmas T, Montoya V, Alonso MC, Vašíček R, Rastrick E, Gaboreau S, et al. Characterization of Cebama low-pH reference concrete and assessment of its alteration with representative waters in radioactive waste repositories. Appl Geochemistry. 2020; 121: 104703.

88. Yildirim IZ, Prezzi M. Chemical, mineralogical, and morphological properties of steel slag. Adv Civ Eng. 2011; 2011: 463638.

89. Fang X, Xuan D, Poon CS. Empirical modelling of $\mathrm{CO} 2$ uptake by recycled concrete aggregates under accelerated carbonation conditions. Mater Struct. 2017; 50: 1-13.

90. Leino T, Aho M, Kauppinen J, Hedman M, Maunula J, Roppo J. Protective power of coal and peat against alkali chloride formation and $\mathrm{Cl}$ deposition in blends with forest biomass in FBC. Proceedings of the 22nd International Conference on Fluidized Bed Conversion, FBC 2015; 2015 June 14th-17th; Turku, Finland. Espoo: VTT. 
91. Rendek E, Ducom G, Germain P. Carbon dioxide sequestration in municipal solid waste incinerator (MSWI) bottom ash. J Hazard Mater. 2006; 128: 73-79.

92. Li X, Bertos MF, Hills CD, Carey PJ, Simon S. Accelerated carbonation of municipal solid waste incineration fly ashes. Waste Manage. 2007; 27: 1200-1206.

93. Siddique R, De Schutter G, Noumowe A. Effect of used-foundry sand on the mechanical properties of concrete. Constr Build Mater. 2009; 23: 976-980.

94. Nduagu E, Romão I, Fagerlund J, Zevenhoven R. Performance assessment of producing $\mathrm{Mg}(\mathrm{OH})_{2}$ for $\mathrm{CO}_{2}$ mineral sequestration. Appl Energy. 2013; 106: 116-126.

95. European Commission. The European Green Deal [Internet]. 2019. Available from: https://ec.europa.eu/info/strategy/priorities-2019-2024/european-green-deal en.

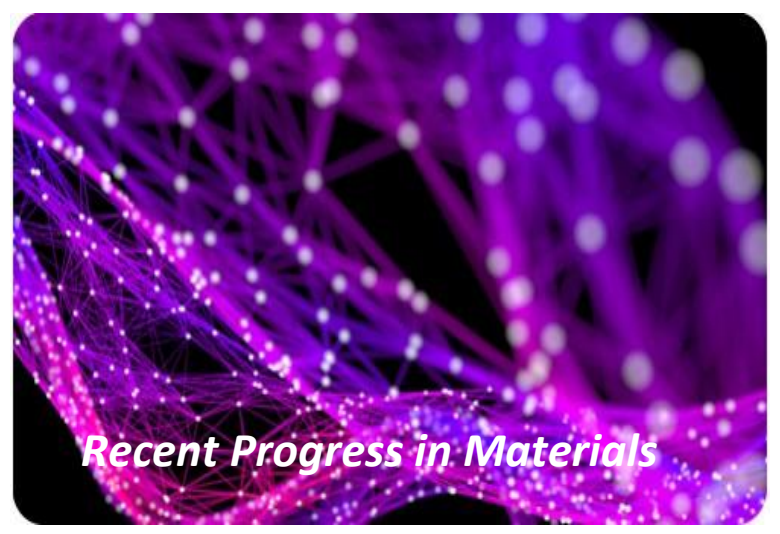

Enjoy Recent Progress in Materials by:

1. Submitting a manuscript

2. Joining in volunteer reviewer bank

3. Joining Editorial Board

4. Guest editing a special issue

For more details, please visit:

http://www.lidsen.com/journals/rpm 